\title{
Introduction: The Matter of Piety in an Age of Religious Change
}

14 Milis 1982, 142.

15 Lutton \& Salter 2007, 2-4.

Van Uytven 1995a. Spicer 2017. Williamson 2014. objects described. 287-3o6. 2007, 111-114.
The objects mentioned in this paragraph will be discussed in detail throughout this book. Steppe 1971; 'Roerende goederen van de SintLeonarduskerk te Zoutleeuw op Vlaamse Topstukkenlijst', consulted 29 January 2019. http://www.kunstenenerfgoed.be/. See most recently Van Bruaene et al. 2016, as well as the other contributions to that issue, and

Thus, the present approach is more objectbased than the 'Christian materiality' in Bynum 2011, 18-32. Compare with Evangelisti 2013 and

By taking Zoutleeuw's church as case study, my focus will inevitably be on public rather than private piety. Although I will argue (in Chapters 2 and 6) that the two cannot be strictly separated, an important part of the religious material culture related to private devotion - including crucifixes, Christmas cribs and prayer books will consequently not be dealt with.

Romein 1946. A well-known reply is Woltjer 1980. Good overviews of the relevant historical studies are provided by Milis 1982; Trio 1993, 15-16; Speetjens 2007; Soen \& Knevel 2013; Bauwens 2015. For the period in question the most important art historical overview still is Bangs 1997. De Groot 2013 is a recent exception that includes discussions of the broader use of the

Huizinga 2009, 210-213 and 229.

Axters 1950-196o, vol. 3, 389-410; De Moreau 1945-1952, vol. 3, 574-593; Post 1957, vol. 2,

Chiffoleau 1984, 252; Soen \& Knevel 2013, 4-5. Toussaert 1963. For an overview of the most important reviews of his book, see Speetjens
Countries are Delmotte 1963; Moreau 1968; Van Uytven 1968; Van der Wee 1968; Van der Wee 1969; Decavele 1975; Backhouse 1976; Marnef 1996; Marnef 2004.

Jonckheere 2012; Spicer 2013.

Dekoninck 2005; Melion 2009; Göttler 2010.

Pollmann 2006.

Pollmann 2011a.

The church's collection is simply too large to be covered in one study. To a large extent, the selection of objects is based on the availability of documentary or contextual evidence. Many of the preserved freestanding sculptures and the 
liturgical textiles or silverware will not be dealt with.

Whereas most series from the Low Countries are fragmented or only start later, comparable sets are available for the Antwerp collegiate church, later cathedral, of Our Lady, and for Utrecht Cathedral and the Buurkerk. See Vroom 1983, 7-8 and 111, note 2; Meyers-Reinquin 1970; De Smet 1970. Most methodological reflection on churchwarden accounts as a historical source is related to England: Foster 1997; Burgess 2002; Kümin 2004; Burgess 2004; Hutton 2005. They have also been used intensively in recent French and German research: Follain 2000; Reitemeier 2005.

For the Low Countries, the basic discussions on the fabrica ecclesiae as an institution are Laenen 1924, 176-195; De Moreau 1945-1952, vol. 3, 369-370; Nolet \& Boeren 1951, 346-347; Post 1957, 427-431; De Smet et al. 2006. The Zoutleeuw fabrica ecclesiae is only briefly touched upon by De Mecheleer 1997a, 10-11 and De Mecheleer 1997b, 10-11.

Compare with Chiffoleau 1984, 265.
De Mecheleer 1997a, quote on 15. See also De Mecheleer 1997b.

RAL, КАВ, Boxes 966 to 986 , as well as three registers with copies, nos. 989, 990 and 991. See Grauwen et al. 1996.

RAL, KAB, nos. 1023-1052. The accounts of the chapter are incomplete and the acta capituli are preserved only from 1593 onwards.

AAM, DV, Z1 and Z2. See Cloet, Bostyn \& De Vreese 1989, 245-248.

RAL, SL, resp. nos. $35^{81-3621}$ and 2976-3065. Four certain confraternities include those of Saint Sebastian (handbowmen), Saint George (crossbowmen), Saint Leonard (arquebusiers) and Saint Anne (chamber of rhetoric). There also was a foundation of the Holy Name of Jesus and the Lauds of the Holy Sacrament (discussed in Chapter 5), but it is unclear whether these were confraternities.

Christian 1981; Terpstra 2013, 266-267.

Recently discussed by Van Mulder 2016.

For the treatises, see Freedberg 1972; Jonckheere 2012; Spicer 2012; Spicer 2013. For the chronicles and diaries, see Pollmann 2011a, esp. 203-206. See also the overview on the Dutch Revolt website (Leiden University).

On the Council, see Marnef \& de Schepper 1994.

On the sentences, see Woltjer 1964.
There is no comprehensive study of representations of church interiors dating to the period under consideration, but useful tools are the online database Missa Medievalis, and Steinmetz 1995. These have been supplemented by a large set of other representations collected throughout the research.

47 Chiffoleau 1984, 250. On the quantitative analysis of accounts for these purposes, see also Mols 1964; Meyers-Reinquin 1969, 212; Aerts 1982, $15^{2}$.

48 Similar remarks by Terpstra 2013, providing further references. A similar chronological scope has also been proposed by Eire 2016.

49 Compare with observations by Minnen 2o11, vol. 1,160 and 169 .

\section{The Cult of Saint Leonard at Zoutleeuw}

KR 1476, fol. 198 (July 1476, 'Doen men die tafele verdincde aen die meester in dy herberghe, betaelt 10 st ende verteert in di herberghe $4 \mathrm{st}$ (...) Item di meesters te Bruessel ghewest om di tafelle te verdinghene'); KR 1477, fol. 220 (March 1478, 'Item van Sijnte Leonaerts tafelen ter cost gedaen metter vragte $6 \mathrm{Rg}$. Item vander selver tafelen te Bruesele ghecocht, cost 126 Rg'); KR 1478, fol. 243 (April 1479, 'Item Henric Wouts vanden jare voerleden van Sijnte Lenaerts tafelen te brijnghene van Mechelen tot Leeuwe').

See most recently De Boodt 2005, cat. A19, and Geelen \& Steyaert 2011, cat. 62. On the contrary, Engelen 1993, 187-205 dated the present altarpiece to 1453 .

3 Poncelet 1910; Van Roey 1910; De Voragine 1995, vol. 2, 243-244. The quote comes from the chants in the Zoutleeuw liturgy: Brussels, KBR, Ms. 21131, fols. 85-86 ('fit medela languidorum, nexus solvit captivorum'). See also fols. $172-174 \mathrm{~V}$ for the hagiography.

4 Jacobs 1989; Jacobs 1991.

$5 \quad$ Cat. Detroit 196o, 239; De Boodt 2005, cat. A9 and B17; Geelen \& Steyaert 2011, 124 and cat. 62. For the De Villa altarpiece, see Jacobs 1998, 188-19o. For de Gauchy's altarpiece in Ambierle see Cat. Brussels 2013, cat. 8 .

$6 \quad$ Woods 1988, 72 and 76.

7 A catalogue of Brussels altarpieces is provided by De Boodt 2005. Compare with the inventory of Netherlandish altarpieces in De Boodt \& Schäfer 2007, 281-291. 
KR 1476, fol. 198 (July 1476, 'Item meester Aert van bewerpene doen hi te Bruesel was te lone ende metter cost 15 st'); KR 1478, fol. 240 (September 1478, 'Item Meester Aert dij moeldere ghegeven ... van dat hij bij dij kerchmeesters te Bruesele ghegaen was om die tafele van Sijnte Leonarts int jaere voerleden ghegeven ter goeder rekenynghen 5 gulden'). The identity of the artist has been a matter of debate. The Zoutleeuw accounts clearly identify him as a painter (scildere or meeldere), excluding the possibility that he was the sculptor of the altarpiece, as was proposed by Piot 1859-186o, 59; Rousseau 189o-1891, 440-446; Destrée 1894, 164-169; Roosval 1933, 137-139. All the available evidence the Zoutleeuw accounts as well as documents published by Van Even 1870, 26-29 - further confirms that he can be identified as De Raet, as had been suggested by Frans Baudouin in Cat. Brussels \& Delft 1957, 166, and Steppe 1971, 616 and 640 . The identification was nevertheless refuted by Hulin de Loo 1905; Van de Ven 1972, 206; Engelen 1993, 158.

Contemporary examples confirm that the involvement of local artists was common practice. De Raet himself would later provide another design for a candlestand, see KR 1482, fol. 89 (July 1482). Another example is provided by Van de Ven 1972, 215. For altarpieces, see Jacobs 1998, 100-101.

Woods 1988, 82-83. Compare with the iconographic sources assembled in Steinmetz 1995. Engelen 1993, 196 has proposed two panels (Antwerp, KMSKA, inv. nos. 127-130) as possible wings of the Zoutleeuw altarpiece, but this is highly unlikely. The present dimensions of the panels $\left(94 \times 5^{8} \mathrm{~cm}\right)$ do not match with the retable's case $(229 \times 241 \mathrm{~cm})$ in any way and they repeat scenes already present in the sculpted part. The backs furthermore depict the entirely unrelated Saints George and Hubert, whereas the altar in Zoutleeuw had Saint Leonard, the 11.000 Virgins and All Saints as tituli.

11 Contrary to what has been claimed by Engelen 1993, 195, technical research has confirmed that the current order of the different sculptural groups is authentic. See Brussels, KIK/IRPA, no. $2 \mathrm{~L} / 47-98 / 6382$.

12 De Boodt 2005; Woods 2005.

13 Jacobs 1998, 113.

14 Cat. Amsterdam 1980, 34-35. Compare with a contemporary Brussels example: Dickstein
2009, 19-23. In general, see Périer-d'Ieteren 1984, 104-105.

15 Such as 140 gulden for the altarpiece commissioned in 1510 from Jan Borman by the Confraternity of the Holy Sacrament in Turnhout: SAL, no. 7404, fol. 39v. Compare with prices in Asaert 1972, 54-55; Jacobs 1998, 175-182; Helmus 2010, 139-144 and 404-410.

16 Proposed by Achter 196o, 254-255, rejected by Marijnissen \& Van Liefferinge 1967,78 , note 13.

17 For instance by Marijnissen \& Van Liefferinge 1967,78 , note 13 .

18 Jacobs 1991; Reinburg 1992, 533-535; Van der Ploeg 2002; Williamson 2004, 365-367; Woods 2005, 91. On the use of the crucifix, see also Hope 1990 and Gardner 1994, 7-9.

19 The only known exception is the much earlier Hakendover altarpiece (c. 1400-1410), where the unrelated crucifixion scene probably is a later addition: Marijnissen \& Van Liefferinge 1967 , 87-88; De Boodt 2005, cat. A15.

20 Woods 2005; D'Hainaut-Zveny 2008, 16o-164.

21 The contract from 1506 for a carved wooden retable on Saint Leonard's altar in the Leuven church of Saint Peter does not request particular scenes either: SAL, no. 740o, fol. 151r; Helmus 2010, 368.

Ainsworth 2010, cat. 9o.

23 De Boodt 2005, cat. A21.

24 Van Roey 1910, 16.

25 Ehresmann 1982; Skubiszewski 1989, 15-18.

26 Jacobs 1991, 46; Jacobs 1998, 94-95; Van der Ploeg 2002.

27 Harbison 199o, 65-73; Williamson 2004.

28 Périer-d'Ieteren 1984, 123. Compare with De Boodt, 2005 and de Boodt \& Schäfer 2007, 281-291.

29 Cat. Toronto etc. 2016.

30 A critical overview of the recent literature is provided by Falkenburg 2007, 180-181.

Compare with Jacobs 1998, 8o-81 and 94-95. Falkenburg 2016.

Lisson 2014a, 413; Lisson 2014b, 12; Lisson 2015. RAL, КАB, Box 966, no. 1 ('ad majorem populi commoditatem'). Published in Bets 1887-1888, vol. 1, 297-298. See also Lefèvre 1942, 32-33. Saint Sulpice's was subsequently donated to the Order of Val des Écoliers in Liège, thus becoming a priory church: Pieyns-Rigo 1970, 1118-1121.

35 Gaier 1968; Lisson 2014a; Lisson 2014b.

36 Miraeus \& Foppens 1723-1748, vol. 3, 729 ('Ecclesiam Sancti Sulpitii esse extra villam sitam, \& esse solitariam'). 
cluding a chapel just outside the Liège city walls (Stiennon 1951, 287-291; Russe 1955, 376) and a leper house in Huy (De Moreau 1945-1952, vol. 6, 250; Dury 2016). Lisson 2014a, 424-425 suggested that the Liège chapter of Saint Denis founded the chapel after the Battle of Steps in 1213 . Lisson 2014a, 425. The basic architectural analysis in Lemaire 1949 198 and $213^{-214}$ is to be supplemented by Leurs 1951; Doperé 1996, 429; Buyle et al. 2004, 39-43. Branner 1963 does not take into account the 1861 reconstruction of the choir.
Bets 1887-1888, vol. 2, 85-86; Laenen 1935, vol. 1, 324-325. The foundation charter of the collegiate chapter (RAL, КAB, Box 966, no. 2O) is published in Miraeus \& Foppens 1723-1748, vol. 3, 730-731. Piot 1879, no. 22; published in Analectes pour servir à l'histoire ecclésiastique de la Belgique 1 (1864), 81-83.

RAL, КAB, Box 966, no. 32bis; published in Delehaye 1926, 363-364. The statements on the document by Wilmet 1938, vol. 1, 233-234 are incorrect. Compare with an other example in Mak 1946, 172. On the requesting procedure, see Swanson 2007, 120-121.

Oliver 1995, 188-19o. Compare with contemporary indulgence bulls awarded to the beguinage church in Diest (1333) and Saint Martin in Halle (1338): RAL, KAB, resp. nos. 13722/ bis and 3066/4.

Cat. Namur 1993, fig. 33, and Brussels, KIK/IRPA, no. $2 \mathrm{~L} 472002$ O7752. A dendrochronological investigation yielded no results, but the original polychromy was found to date after c. 1330. I am grateful to Emmanuelle Mercier for sharing this information with me. Earlier dates were proposed by De Borchgrave d'Altena 1924-1925; Steppe 1971, 615; Buyle et al. 2004, 45.

Fricke $2015,13^{-16}$.

Coens 1598, fol. 206v-207; Cramer \& Pijper 1903-1914, vol. 1, 196. However, in line with the Tridentine decree on images, many theologians continued to use generical terminology (sacris imaginibus). See, for instance, Molanus 1996. Vauchez 2004; Trexler 2004, 21; Walker Bynum 2011, 22.

Van Herwaarden 1978, 486-487, notes 6 and 7. RAL, SL, no. 3581 , account of 1437 , fol. 10 ('smaendachs in die tsinxen dach doen men Sinte Lenart om droech'). The account of 1434 is the one preserved immediately preceding the 1437 account, suggesting that the procession had been instituted somewhere in between these years. Other proposed dates of origin are 1274 (Bets 1887-1888, vol. 2, 87-88; Lisson 2014b, 16-19) or 1328 (Buyle et al. 2004, 38), but analysis of the civic accounts proves these assumptions wrong.

$5^{\circ}$ Doperé 1996, 429. The current location of Saint Leonard's altar in the southern transept is due to a relocation in 1820: DAZ, no. 45, 142; Piot 1859-186o, 59 .

$51 \quad$ '... Atrio, Vorstius, Kemerlinc were the first ... to cover, in the year of Our Lord 1440, in the month of October, the $17^{\text {th }}$ day ... with paint', personal reading on 9 March 2016. Wilmet 1938, vol. 1, 239 and Doperé 1996, 429 provided transcriptions with minor differences.

$5^{2}$ Bets 1887-1888, vol. 2, 127-128 and 200; Wilmet 1938, vol. 1, 238.

53 Brussels, KBR, IV 42.129A, fol. 146v; Breugelmans et al. 1987, 61; Brigode 1936, 91.

54 Gerevini 2015.

55 See Coveliers 1912, 92-93, Haslinghuis \& Peeters $1965,456-458$, as well as BALaT, object nos. 83325 (Berlaar); 10142268 (Notre-Dame de Soleilmont); 46921 (Handzame); 49820 (Tongeren); 71632 (Peer); 4045 (Aarschot); 81285 (Drogenbos); $55^{293}$ (Leuven).

56 See Grauwen et al. 1996, nos. 632, 709, 762, 774, $781-782,785,833,835,842,849,855,858,863$ and 922.

57 RAL, SL, nos. 2986 and 2987; Grauwen et al. 1996, nos. 547, 712, 715, 718, 720, 721, 733 and 736 .

$5^{8}$ Roggen \& Withof 1944, 129-138; Cheyns 1979, 146-152.

59 '(...) ut ipsi christi fideles eo libentius devotionis, orationis et peregrinationis causa confluant ad eamdem (...)' The text of the charter is known in an eighteenth-century transcription (DAZ, no. 45, 141-142), published by Bets 1887-1888, vol. 2, 127, note 1. For Stephani, see Ernst 1806, 132-133.

60 'Joannes de Katen et Maria ejus uxor fundaverunt hanc cappellam et in ea fundaverunt missas secundum litteras Joannis Episcopi Leodiensis 23 septembris 1442'. DAZ, no. 45,141 . The Mass is referred to yearly in the churchwarden accounts from 1460 to 1473 .

61 Doperé 1996, 429.

62 Geary 1986, 176-180.

63 The best overviews are Van Cauwenbergh 1922, esp. 138-139, and Van Herwaarden 1978. For Brabant, see Vanhemelryck 1993. 
64 Van Herwaarden 1978, 703. I am grateful to Jan van Herwaarden for sharing his additional data with me.

65 Vanhemelryck 1993, 155

66 Peeters 1956, 56-64.

67 Brouwers 1965; Roobaert 2001; Vandevenne 2005.

68 Peeters 1956, 64; Vanhemelryck 1993, 151.

69 KR 1479, fol. 266 (May 148o): 'Smaendaechs in dij Puynxendaghe (...) verteert dij speelliede ende die dienaers ende die pelgrijme tsamen 15 st'. In the same account, the receipt of 3,5 stuivers for a beaten pelgrym's pall (fol. $257 \mathrm{v}$ ) was also registered.

70 Compare with Burgess 2002, 309-310, and Hutton 2005, 66-69.

$71 \quad$ KR 149o, fol. 29v ('ghebacken te Pinxten voir die pelgheryme'); KR 1492, fol. 75; KR 1493, fol. 107v; KR 1496, fol. $157 \mathrm{~V}$. The conversion from halsters to liters is based on Doursther $1840,35^{6}-35^{8}$.

$72 \quad$ KR 1483, fol. 116v (April 1484, 'Item gegeven den custers van luyden doen Sinte Leonart mirakel deede'); KR 1487, fol. 303 (May 1488, 'Item den pelgherym gegeven dair Sinte Leonart mirakel over ghedaen heeft'). An earlier entry might also refer to a miracle, but the terminology used is ambiguous: KR 1459, fol. $210 v$ (April 146o, 'Item om gode gegheven Willeken die Sinte Leonart verloest hadde').

73 Verhoeven 1992, 139-144. For ex-votos, see Signori 2002, 441; Holmes 2009; Blick 201ob; Blick 2011; Weinryb 2016. Van der Velden 200o, 213-222 provides a classification. For crutches in particular, see Craig 2010.

74 The first recording is KR 1466 , fol. $354 \mathrm{~V}$ ('ontfaen van gheoffert coren'). KR 1503 , fol. $4 \mathrm{~V}$ is the first in the subsequent series of entries.
KR 149o, fol. 44 (March 1491, 'Item den wapenmekere betaelt voir tharnas scoen te maken dat voir Sinte Lenart hinct'); KR 1493, fol. 114 .

Meindersma 1973; Meyers-Reinquin 1969, 215. The earliest accounts refer to 'both boxes' ('beyder stocken'): KR 1452, fol. 14.

KR 1478, fol. 236v ('stocke aen dy doere' and 'stocke in Sijnte Leonaerts coer'); KR 1479, fol. 258 ('wytten stocke ontfanghen in Sijnte Lenaerts coer bijden autaer' and 'stocke aen dij coer doere').

81 KR 1497, fol. 191v; KR 150o, fol. 13v-14; KR 1555, fol. 199v.

82 For instance KR 1453, fol. $36 \mathrm{v}$ ('Item dat ter clocken geoffert was ter Scoliere'); KR 146o, fol. 244v ('Item vanden offere vander schellen dy ter scolieren hinc'); KR 1479, fol. 258 ('Item ontfanghen van Roeben Cloets dat hij te hulpen ghegeven heeft tot Sijnte Catelijnen tafele te stofferene'); KR 1483, fol. 111 ('Item ontfanghen vander deeckene Sinte Leonarts te hulpen sijnen backen te makene').

83 Compare with Marnef 1996, 83-84.

84 Brussels, KBR, IV 42.129A, fols. 145 and 146v-147.

85 Compare with miniatures depicting the cult of Saint Adrian in Geraardsbergen: Maredsous Abbey, Ms. $\mathrm{F}_{3}{ }_{3} / 1-4$, vol. 4 , fol. 1, and Van der Velden 2000, 220, fig. 108.

86 Van Autenboer 1993, vol. 2, 535-539.

87 'Item op Sinte Leonaerts dagh sal elcke geselle (...) te kercke gaen tot eender gesonghe misse, die de Camer oft Gulde alsdan sal doen singhen in Sinte Leonaerts choor, ende dat eenigelyck daer sal brenghen synen offer (...)' Published in Bets 1887-1888, vol. 2, 284-292, quote on 288 .

88 See for instance Mol 1986; Trio 20o9; Suykerbuyk 2017.

$89 \quad$ 'Van enen goeden man van offer' or 'van eender goeder herten'. See for instance KR 1523, fol. 64; KR 1516, fol. 10v; KR 1520, fol. 13; KR 1540, fol. 209; KR 1572, fol. 519v.

9o 'Item ontfanghen van eender vrouwen die des nyet bekent weesen en woude in behulpe Onser Liever Vrouwen tafel te schilderen'. Cat. Amsterdam 1980, 65.

$91 \quad$ KR 1500, fol. $13 v$ first mentions 'haechmunten', i.e. coins that have not been issued or ratified by the government. See the online Woordenboek der Nederlandsche Taal. Later accounts also refer to 'Liège money' (Luydicks gelde). See for instance 
KR 15O7, fol. 12v. On illegal or broken coins as offered gifts, see also Nilson 1999, 110-111. Van Der Wee 1963, vol. 3, 26-27, Graph 7. The real wage index was calculated on the basis of Van Der Wee 1975, 436-447 and Jacks \& Arroyo Abad 2005. I am grateful to Erik Aerts for his valuable suggestions. Van Uytven 1980 and Willems 1998, 266. The churchwarden accounts of these years feature notably more people in the lists with financial exemptions (cortsel), often specified as a result of damages caused by soldiers.

Van Houtte 1952, 198-199; Van Uytven 1980, 434-435; Spufford 2012. Van Gelder 1951 provides a complete overview of the monetary ordinances issued in the Low Countries under Maximilian.

Van Uytven 1974, table IV; Van Uytven et al. 2004, tables 6.5 and 6.7.

The construction of 'dij nouwe camere staende achter Sijnte Leonarts coer' is amply documented in KR 1478, KR 1479 and KR 148o, passim. Compare with KR 1503, fol. 29, where it is described as 'our room' (ons camere). A 1625 church inventory describes it as the 'tresorij oft camer der fabrijcken', see De Ridder 19o8, 47. KR 1486, fol. 252; KR 149o, fol. 42v; KR 1504, fol. 2Ov ('Item betaelt Henricken Strookorff om tspel van Sinte Leonart te scrijven op franchyn, dwelck altyt blijven sal in Sinte Leonaerts camere'); KR 1573, fol. 403 ('den ontbijt ende noenmael inde camer voer mans ende vrouwen die opden offer ende metten wasch voert gheseten hebben'). In KR 1520, fol. 1, for instance, they present themselves as 'momboren ende provisoers van Sinte Leonarde te Leuwe'.

KR 1453, fol. 37v (July 1453, 'van den tabernakelen te makenne aen parvijs ... Everart van den drie tabernacelen te stofferen'), fol. 38 (August 1453, 'Everaert van drie stenen te stofferenne aen poertael'). KR 1453 (Draft), fol. 63 specifies that the tabernacles were made by 'die huwars van Brusele', and that also three figurative sculptures (bielgen) were polychromed. The construction of the 'new' portal in the west front (neuwen provise) is documented in KR 1525. KR 1479, fol. 265 (May 1480). For the meaning of these terms, see Doperé 1997-1998, 95, and Doperé 2000, 125-128.

101 Kavaler 200o; Kavaler 2012.

102 'Leonardum, cuius nomen tam iocundum floret in ecclesia', Brussels, кв R, Ms. 21131, fol. 85 .
103 Vroom 1981, 40; Somers 2015, 157-159.

104 An in-depth analysis of the chapter's accounts might provide more information on their share.

105 KR 1477, fols. 219v (March 1478) and 221 (May 1478).

106 In general, see Blick 2o1oa, and Freedberg 1991, 124-126. On their different uses, see Koldeweij 1999; Van Loon van de Moosdijk 2004, 85-114; Van Asperen 2009; Foster-Campbell 2011; Rudy 2016.

107 Van Loon van de Moosdijk 20o4, 54-56, 94, 102-103, 450-461.

108 Cohen 1976; Nilson 1999, 116; Soergel 1993, 52-61.

109 KR 1478, fol. 242v (March 1479): 'Item betaelt den selven Joese [Beyaert] van eender vermen daer men Sijnte Lenaerts byelden in ghyet'.

110 Compare KR 1484, fol. 133v (July 1484, 'Item Meeus vander Molen gegeven van selveren tekenen te makene') and KR 1487, fol. 301 (January 1488, 'Item betaelt Vrancken den Ketelbueter van tinne dair tekenen af ghegoten sijn'). See further KR 1487, fol. 3O2v (April 1488); KR 1489, fol. 325V (May 149o); KR 149o, fol. 45V (June 1491).

111 KR 1491, fol. 65 ('Item den canghietere van beelden te ghietene betaelt'); KR 1492, fol. 88 (June 1493); KR 1493, fol. 119v (June 1494); KR 1495, fols. 143V (May 1496) and 145 (June 1496); KR 15O2, fol. 439v (June 1503).

112 KR 1503, fol. 18v (August 1503); KR 1509, fol. 41V (July 1509, 'Item betaelt vanden (...) pampier roet te makene aende beelden van Sinte Leonaerts voer de pelgrijms'); KR 1510, fols. 573 (October 1510) and 574V (December 1510); KR 1520, fol. 21v (May 1521); KR 1523, fols. 66v (August 1523) and 68v (November 1523).

113 Van Beuningen \& Koldeweij 1993, 178, figs. 276, 277 and 278; Van Beuningen et al. 2001, 277, fig. 1188.

114 Compare, for instance, with the egg-shaped face with beady eyes in Beyaerts' Zoutleeuw Saint Catherine (fig. 48). For the pilgrim badges from Dudzele and Saint-Léonard-de-Noblat, see Koldeweij 1987; Van Beuningen \& Koldeweij 1993, 176-177; Van Beuningen et al. 20o1, 276-277. On Beyaert, see Crab 1977, 219-225 and passim.

115 Minnen 2011, vol. 1, 107.

116 Compare with the observations by Nilson 1999, 116.

117 KR 1483, fol. 11ov ('ontfangen van (...) twe jair hueren als van stadghelde int parvijs'); KR 1485, fols. $185 \mathrm{~V}$ ('ontfangen van Art der Juwelier van 
staene int parvijs') and 186v ('ontfangen van Lippen der Cremer van sijnen staene inden parvise'); KR 1487, fol. 296; KR 1489, fol. 321v; KR 1491, fol. $59 \mathrm{v}$.

118 KR 1484, fol. 137v (April 1485): 'Item ghegeven vanden bullen vanden aflate van Roemen gesonden, 4 Rg'.

119 A 1625 church inventory still mentions several indulgence bulls, without any specification: 'Daude ende neeuwe bullen van de indulgentien (...) Daude besegelde bulle vander indulgentien metten grooten zegelen. Die neeuw indulgentien deur Paulus papa verleent'. De Ridder 1908, 53-54. Weigl 2010; Tingle 2015, 54-55.

121 Soergel 1993, 29-43; Nilson 1999, 113-114; Morris 2011, 335-340.

122 For examples, see Fredericq 1922, 252, no. 181; Fournier 1923; Prims 1939, 105, 109, 114; Van de Ven 1972, 208, note 6; Nilson 1999, 113-114.

123 Compare with Trio 1993, 282-283. On indulgences in general, see Shaffern 2006; Morris 2010; Bird 2010.

124 Lewis 1992; Caspers 20o6, 72-76; Morris 2011.

125 Nixon 2004, 83; Swanson 2007, 162. For altarpieces in particular, see Van der Ploeg 2002, 112-113.

126 KR 1477, fol. 219 (February 1478): 'Item Meester Aert vander molerijden te makene in Sijnte Leonaerts coer ende metten cost samen 20 Rg'.

127 KR 1476, fol. 202 (June 1477): 'di stellinghe te Lintere ghecocht Sijnte Lenaert werck mede te makene'. See also KR 1477, fol. $217 \mathrm{~V}$ (September 1477).

128 The composition of the Last Judgment is closely related to the lost painting of the same subject that Dirk Bouts painted for the city of Leuven in 14681469, known through an anonymous copy (Munich, Bayerische Staatsgemäldesammlungen). See Buyle \& Bergmans 1994, 188-189; Périer-d'Ieteren 2005, 69 and cat. 16-18. For these mural paintings, see also Raes 1995, cat. 34 and 35, and Geelen \& Steyaert 2011, cat. 65 .

129 KR 1480, fol. 4Ov (June 1481): 'Item ghegeven Joes Beyaerts van eender nouwer cassen daer Sijnte Lenaert in sal staen te makene'.

130 For examples of depictions, see Steinmetz 1995, cats. TB3, TB9A, TB68A, TB71, TB86, TB87, TB88, TB97A, BM2, BM7, BM9, BM11, BM40, BM54, $\mathrm{BM}_{71}$ and $\mathrm{BM}_{76}$; Steyaert 2015. For a preserved example, see Didier 1995. On the practice and its origins, see Van der Ploeg 2002, 108.

131 Steppe 1971, 636-638.
132 KR 1480, Fol. 3ov (June 1481); KR 1481, Fol. 65 (April 1482, 'Item betaelt Meester Aert dij Scildere van Sijnte Lenaert te stoffere (...) ende noch vander nouwer cassen te stofferene').

133 KR 1481, fol. 66v (June 1482): 'Item ghecocht teghen Tonys van Liere der capmekere een cleet voer Sijnte Lenarts autaer te hanghene te hoghentijde ende op dij heyleghe daghe'. See for this embroiderer also KR 1480, fol. 27V (September 1480) and KR 1486, fol. 247V (November 1486).

134 On van Thienen, see Duverger 1939; Frederiks 1943; De Ruette et al. 1993.

$135 \mathrm{KR}$ 1481, fol. 65V (May 1482, 'Item verdinct te makene teghen Meester Reynder van Thienen, gheelghieter te Bruysele enen luymenarys voer Sijnte Lenaert staende in sijnen coer na dy maniere van Sijnte Goedelen te Bruysele'); KR 1482, fols. 89v (July 1482, 'Willem van Halle, Reynder Froeytens ende meester Art di scildere doen si te Bruesel gheweest waren om den kendelere te verdijnghene (...) Item meester Art der Scildere ghegeven van enen patroen te beworpene ende van 2,5 daghe mede te gane te Bruesele') and 93; KR 1483, fol. 114V (November 1483).

136 Bets 1887-1888, vol. 2, 13 o and 140-141.

137 See for instance KR 1505, fol. 25 (June 15o6, 'Sinte Leonaert daerboven').

138 Bruijnen 1997; De Boodt 2005, cat. A18.

139 KR 1482, fol. 93 ('Item verdinct te makene teghen meester Reynder van Thienen, gheelgieter te Bruyesele, enen candelare staen sal inden hoghen coer na tenoer ende na di maniere van Sijnte Peters te Lovene'), and KR 1483, fol. 114r-v (November 1483, 'enen luminaris inden hogen choer'). For the candlestand, see also Cat. Leuven 2019, 71, 175, 192.

$140 \mathrm{KR}$ 1482, fol. 93 ('twe blau steene daer die posten metten ynghelen op staen'); KR 1483, fol. 114V (November 1483, 'vanden voete te houdene dair den luminaris op staet').

141 De Ridder 1909, 148: 'De Choor van St Lenaert heeft: (...) Twee coeperen pilaeren; op elk pont van die pilaeren staen eenen coeperen engel; aen dien met het cruys inde hand mankeert eenen vleugel. Een loop soo breet als de coer is met een uytgewerkt werk'. De Ridder dated the inventory to c. 1810 .

142 In general, see Randall 1959. For other documented examples in the Low Countries, see for instance Prims 1939, 122; De Mecheleer 1997a, 31. 
143 As had been proposed by Frederiks 1943, 123-125, and Steppe 1971, 613-614 and 646-647. On the Xanten candelabrum, see Klapheck 1941, 73-74, and Beissel 1966, 22-25. For a different interpretation, see Engelen 1993, 146-148. Straus 2012, 156-157. Similar structures are depicted on a miniature in a Book of Hours (Vatican City, Biblioteca Apostolica Vaticana, Vat.lat.3769, fol. 66v), on the last painting of the Cologne Saint Severin cyle of c. 1500, and on Colyn de Coter's Veneration of the shrine of Saint Stephen (Enghien, Capucine Convent). See respectively Cat. Los Angeles 2003, 374-376; Oepen \& Steinmann 2016, 48-49; BALaT object no. 10019283 .

De Blaauw 2012.

Oral communication by conservator Ward Hendrickx (9 March 2016), who still knew the original disposition. Furthermore, given the location of the preserved hole, quite far in the southwestern corner, a north-south orientation would have been quite strange, as the candlestand would have stood near the western wall.

De Blaauw 2012, 40-45; Arneitz et al. 2014. See for instance Jan de Beer's Joseph and the suitors (Birmingham, The Barber Institute of Fine Arts, inv. 51.5) and Adriaen Isenbrandt's Mass of St Gregory (Madrid, Museo del Prado, inv. Poo1943).

149 De Jonge 1993, 92-94; Delbeke et al. 2015, 233.

$15 \mathrm{O}$ KR 1483, fol. 111: 'ontfanghen vander deeckene Sinte Leonarts te hulpen sijne backen te makene'.

151 Verhoeven 1992, 55-56 and 62-63. Compare with Vroom 1981, 347-348 and 351; Verhoeven 1986, 205, 210, 214 and 220; Leysen 2001-2002; Mertens 2012; Purkis 2010.

$15^{2}$ Saintenoy 1911-1913; Vanhoof 2015.

153 A biographical summary of Jan Mertens is provided by Asaert 1972, 68-69, but the information he provides on his activities for Zoutleeuw is inaccurate.

154 KR 1478, fol. 242v (March 1479, 'betaelt Joes Beyaerts van eender tafele te makene di op Sijnte Catelijnen autaer staet'), fol. 243 (April 1479), fol. 244 (June 1479, '1 tafele ghecocht tot Antwerpen die opden hoghen autaer steet te Jan Mertens dij bieldescnydere').

155 KR 1480, fol. 3ov (June 1481): 'noch ghegeven den selven Joese [Beyaert] op 2 backen dij hij verdinct heeft te makene op Sijnte Jans Ewangelijsten autaer ende op Sijnte Claes autaer'.

156 KR 1482, fol. 92v: 'die drie backen metten bielden en Sijnte Jacop teghen Jan Mertens van Antwerpen'.

157 KR 1483, fol. 116 (March 1484): 'den back oft tafelle op Sint Jans Baptisten altair'.

$15^{8}$ KR 1484, fols. 137r-v (March 1485): '[Jan Mertens] noch betaelt vanden tafelen van Sinte Cristoffels ende Sinte Joris (...) Item verdinct tjeghen Janne Mertens eene tafele vander Drivoldicheit, Sinte Anthonis etc'. KR 1484 (Draft), fol. 478v specifies the third altarpiece in adding 'ende Sinte Cornielis'.

159 KR 1453, fol. 39: 'Item die tafele in Sinte Leonarts choer, cost 16 gripen. Item Willem van Colene vander tafelen te stofferenne 12 gripen 3 st'. Engelen 1993, 187-205, on the contrary, identified this altarpiece as the one now preserved in the church.

16o Compare with Vauchez 2004, 13.

161 Compare with Davies 2004, 79.

162 Freedberg 1991, 99-135, esp. 103 and 109-110, quote on 118. See also Bergmann 2017.

'Miraculous charisma' is borrowed from Trexler 2004, 23.

163 Kavaler 2014.

164 Geary 1986, 18०; Fricke 2015, 15-16.

165 Finucane 1975 .

166 KR 1481, fol. 58v.

167 Van den Broeck \& Soens 2017, 8o-81; Curtis et al. 2017, 124-125 and $135^{-136 .}$

\section{The Image of Piety at the Dawn of Iconoclasm}

Christian 1981; Terpstra 2013, 266-267; Soen \& Knevel 2013, 9-10.

2 Post 1957, vol. 2, 266-267 and 288f.

3 Eire 1986, 10-11.

4 Moeller 1965. Compare with Walker Bynum 2011, 18-19, 32 and 268.

5 Moeller 1965, 22 ('eine der kirchenfrömmsten Zeiten des Mittelalters').

6 On the Baufrühling in particular, see Göttler 1990, 285-286.

$7 \quad$ Soergel $1993,20-27$ and 43 .

$8 \quad$ Nixon 2004, 31-38.

$9 \quad$ Kühnel 1992, 105-107; Soergel 1993, 52-61.

10 Dhanens 1987, 118-119; Nixon 2004, 21-27.

11 Febvre 1929, 39; Galpern 1974, 175; Chiffoleau 1983, 129. 
Blick \& Tekippe 2005, xxi; Soergel 2012, 34-35. A general discussion of medieval pilgrimage with a large geographical and chronological scope is Webb 2002.

Weiler 1980, 438 noted 'groeiende intensiteit van vroomheid', but referred to Moeller and did not elaborate on it.

General discussions of the source type include Signori 2002, 441-447; Hofmann-Rendtel 1992; O'Sullivan 2010; Purkis 2010; Gross-Diaz 2010.

Finucane 1975, 10.

Finucane 1977; Van Mulder 2015a.

Signori 2002, 438-445.

This topic will elaborately be discussed in Chapter 8. On the seventeenth-century reception of medieval miracle books, see Thijs 1996, 276-281, and Van Mulder 2016, 335-35o.

Lipsius 16o4, 65-66.

Van Roey 1910, 29, Wilmet 1938, 335 and Buyle et al. 2004, 38 claimed that the miracle book got lost under the French occupation, but no contemporary reference is known.

Van Mulder 2015b.

Overviews of the material are available in Giraldo 1959a; De Boer \& Jongen 2015, 19-20; Van Mulder 2016, Appendix 1 and passim. These are to be supplemented with Vrancx 16oo; Historia 1674; George 1998; Minnen 2o11. For evident reasons only dated miracles were used and only collections with pre-1550 origins were included in order to focus on the long-term evolution of piety. The chronological and the numerical scope of this dataset is comparable to Finucane's (2300 miracles from 1066 to 1300 ), although he only studied nine sites. See Finucane 1977, 9-14. Mertens 2012; Van Mulder 2016, 119-120. De Boer \& Jongen 2015; Van Mulder 2015a; Van Mulder 2016, 79-83.

The Amersfoort data have been left out here, as its 542 miracles represent more than one fourth of the whole dataset and thus proportionally outweighs all other shrines and distorts the curve.

Phrases borrowed from Platelle 1968, 45, and Johnson 1996, 202.

In general, see Shaffern 20o6; Swanson 2007; Morris 2010; Bird 2010; Tingle 2015. For the Low Countries and the historiographical issue, see Van Herwaarden 2003a and Caspers 2006.

Compare with Caspers 2006, 66 and 92. A recent revision is Sugiyama 2017.

Shaffern 2006, 11. 
I studied. In general, see Smeyers 1994. Hendrik Roesen's work is documented in KR 1496, fol. 168; KR 1503, fol. 18, 27v-28 and 29; KR 1504, fols. $15 \mathrm{~V}$ and 18. For Peter and Claes Roesen, see also Chapters 4 and 6.

Contemporaneous examples of chandeliers are in Bocholt, Bruges and Xanten, see respecitvely BALaT object nos. 78276 and 108541, and Klapheck 1941, fig. 53. An example of an epitaph is in Nivelles, see BALaT object no. 101496og. Examples in Rudy 2012 and Sugiyama 2017.

Cat. Toronto etc. 2016, 232-235 and cat. 35. For the use of such objects, see Falkenburg 2016. For this and similar examples, see De Boodt related are the Brussels altarpiece of Sala and the 1516 Antwerp altarpiece of Västerås, both showing each of the themes in one of the two openings. See, respectively, De Boodt 2005, cat. B34, and BALaT object no. 40001372. Other examples in De Borchgrave d'Altena 1959 and D'Hainaut-Zveny 1992-1993, esp. 55-56. To these should be added Jheronimus Bosch' and the 1520 polyptych with the Death of the Virgin by Bernard van Orley (Brussels, Museum van het OCMw, BALaT object no. 20000373). Compare also with Hoffmann 2004-2005, figs. 2-3 and 6-7.

Williamson 2004.

This process has been first described in of Saint Gregory in particular, see Falkenburg 2007 and Falkenburg 2015.

This fictive example is based on the analysis in Falkenburg 2007.

Contrary to what has often been supposed (see 2005, cat. B30, B35, B38, B40, B41 and B43. Closely Adoration of the Magi (Madrid, Museo del Prado) Falkenburg 2001. For the iconography of the Mass Falkenburg 2007, 196), there is clear evidence that Masses were performed in front of closed altarpieces on normal days. See, for instance, the c. 1475-1479 miniature in Brussels, KB R, Ms. $9272-76$, fol. 55 ; the c. 1520 miniature in Kassel, Landesbibliothek, Ms. 50, leaf 27; the contemporary panel depicting the Mass of Saint Agilolf in Cologne, Wallraf-Richartz Museum. See, respectively, Cat. Los Angeles 2003, 16o, fig. 28a; Biermann 1975, 129, fig. 169; Steinmetz 1995, cat. TB7B. For the opening and closing of altarpieces in general, see Fabri 2009, 39-41, and Helmus 2010, 48. To the examples mentioned in these publications can be added the one in Cat. Amsterdam 1980, 63 .
64 Compare with Reinburg 1992, 533-535.

65 Falkenburg 2016, esp. 118 and 125.

66 Compare with observations by Walker Bynum 2011, 24-25, 36 and 267-27o.

67 In classical Latin peregrinatio meant 'trip' and peregrinus 'stranger'. Halkin 1969, 240.

68 For the definition, methodological remarks and relevant references, see Margry \& Caspers 1997-200o, vol. 1, 12-16. See also Margry \& Post 1994.

69 Verhoeven 1992, 123-127. Compare with Duffy 2002.

70 Van Herwaarden 2o03b, 205-210 lists medieval destinations in the present-day Netherlands.

71 An example is Sannen 1950. For other relevant literature, see Margry \& Caspers 1997-200o, vol. 1,36 , note 149 , and 43 , notes $212-214$.

72 Thijs 1996; De Roeck 2003.

73 See Margry \& Caspers 1997-200o, vol. 1, 21 for methodological remarks.

74 Van Heeringen et al. 1987; Van Beuningen \& Koldeweij 1993; Van Beuningen et al. 2001. Most data are available in the online Kunera database.

75 Roobaert 2004, 2-15.

76 Roobaert 2001.

77 Mak 1946; Van Haver 1993. For the surroundings of Zoutleeuw, see Hansay 1913.

78 See, for instance, Kühnel 1992, 95, and HofmannRendtel 1992, 129.

79 Verhoeven 1992, 123-127; Margry \& Caspers 1997-200o, vol. 1, 26, note 106. Compare with Duffy 2002.

8o Verhoeven 1992, 123-127.

81 Viaene 1974. Compare with Verhoeven 1986, 217-219.

$82 \quad$ Kruip 2oog; Kruip 2010; Kruip 2011.

83 Compare Van Heeringen et al. 1987 and Kruip 2010, 17.

84 'Sum leo, sum nardus, michi nomen est Leonardus, femineos artus anxiatos pondere partus, demone vexatos ac compede solvo ligatos'. See Steppe 1971, 6o8, and Van Loon van de Moosdijk 2004, cat. 109. Compare with Sannen 1950, 322-323, 377-378, 380-381 and 384 .

85 Hofmann-Rendtel 1992, 129-131.

86 Stiennon 1951, 29o; Russe 1955; George 2001, 264. Judiciary pilgrimages are documented in the later 14th century: Van Herwaarden 1978, 486 (note 6) and 696 .

87 Mak 1946, 16o; Koldeweij 1987; Van Heeringen et al. 1987, 8o-83; Dombrecht 2014, 283-284. 
Michielsen 1887, 23-24; Goetschalckx 19o9, 124-129; De Roeck 2003.

89 Merkelbach van Enkhuizen 1949, 39-40; Toebak 1995, vol. 1, 88-89.

Goetschalckx 1910, 399-4O2; Van Heurck 1922, 4-5.

Van Heurck 1922, 220-224; Roobaert 2001, 142. Beegden, Donk, Peutie, Pont-à-Râches,

Schaelsberg, Vlierbeek and Wanssum. See Sannen 1950, 322-323, 377-378, 380-381 and 384; Coningx 2009, 108-115; Margry \& Caspers 1997-200o. On Pont-à-Râches, see Platelle 1973, 229 and Rayssius 1628, 446-448.

Margry \& Caspers 1997-2000, vol. 1, 25. 'In het selve jaer [1475] begost tot Lier aldereerst St Gummaers mirakelen te doen'. Van Havre 1879, 18. See also Vroom 1983, 52-53 and 106.

Mertens 2012.

On the ritual of elevation and its importance for the revitalization of cults, see Geary 1986, 177-180.

Van Heeringen et al. 1987, 94; Meuris 1993, 59, 62, 64-67, 78, 99 and 125 .

Wichmans 1632, 498 ('ita quoque antiquissimo Deiparae cultu').

Van Haesendonck 1982; Breugelmans et al. 1987. Peeters 1956, 61; Gerits 1983; Van Heeringen et al. 1987, 91-93.

Van Beuningen et al. 1987; Cuypers 1989 . In 1509, 1510 and 1525-1526: Roobaert 2001, 142. Van Beuningen et al. 1987; Delbeke et al. 2015, 231-232.

Van Bruaene 2008, 65; Speakman Sutch 2015, $40-42$.

Minnen 2011, vol. 1, 37-39.

Mak 1946, 16o.

Minnen 2011, vol. 1, 49-50.

Hoc 1937; Van Beuningen 199o; De Kroon \& Minnen 2011. A selection from the churchwarden accounts has been published by Erens 1939 .

Peeters 1956, 61-62.

Roobaert 2001, 142-143.

Soergel 1993, 59-6o. See also Signori 2002, 446;

Kühnel 1992; Hofmann-Rendtel 1992; Nixon 2004, 89; Blick \& Tekippe 2005, xxi.

Van Mulder 2015b.

'Ea [Aedem D. Leonardi] ex collatitia stipe et eleëmosynis accurentium ad famam miraculorum interventu istius Divi patratorum, aucta et multum exornata est', Gramaye 1968, 131. Reitemeier 2005, 615 .
115 Vroom 1981, 276. Another example is Kortrijk: Meyers-Reinquin 1969, 215.

116 Peeters 1982; Van Uytven 1995a; Van Uytven 1995b.

117 Van Uytven et al. 2004, tables 6.5 and 6.7.

118 Only from 153 o (KR 1530, fol. 155) onwards were the churchwardens paid a modest yearly compensation of 4 Rijnsgulden.

119 Roffey 2006.

120 A term borrowed from Monnet 2010, 108 and 115.

121 KR 1484, fol. 135V (November 1484, 'Item den senghers bij bevele der borgenmeesteren'); KR 1486, fol. 248v (January 1486); KR 1487, fol. $3 \circ 3$ (May 1488); KR 149o, fols. 45 (April and May 1491) and $45 \mathrm{~V}$ (June 1491, 'Item den senghers betaelt voir haeren dienst die ere vander kercken te vermeerderen te Pinxten'). Compare with van Autenboer 1983,411 , note 8 .

Richard 2010.

123 Brand 2003.

124 On Geel, see Van Heeringen et al. 1987, 86-88. In general, see Kühnel 1992, 99. For similar patterns in the $17^{\text {th }}$ century, see Harline 2002 and Perneel 2oo9, 350-353.

Moeller 1965. Compare with Zemon Davis 1974, 315 .

Soergel 1993, 49 and 58; Soergel 2012, 33-34;

Signori 2002, 447-458.

127 Price 1994.

128 Cunningham \& Grell 2000, 1-18.

129 Chiffoleau 1983, 129.

130 Brown 2007, 188.

131 Speakman Sutch \& Van Bruaene 2010; Marnef \& Van Bruaene 2016, 189-19o.

132 Dhanens 1987, 118-119.

133 Fried 2016.

134 Kühnel 1992, 95-96.

135 Van Engen 2008.

\section{The Waning of Medieval Piety?}

This paragraph is a partial reworking of Suykerbuyk \& Van Bruaene 2017. Van Gelder 1972, 181-200; Huysmans et al. 1996, 104-108; Timmermann 2009, 327-328; Monumenten, landschappen \& archeologie 28,3 \& 4 (2009). The iconography is discussed in detail by Ceulemans 2009 .

3 'Hier leyt begraven die Eedele Joncker Marten van Wilre, heerre van Oplinteren, hy sterf int jare ons heeren 155813 december ende joffrou Maria 
Pylliepeerts syn huysvrouwe die sterf anno 1554 23 december ende hebben ter eerre Goedts dit sacraments huys hier gestelt'. RAL, SL, no. 3033, fols. 2r-v, first published by Wauters 1868. See also Huysmans et al. 1996, 105-106, and Van Ruyven-Zeman 1998, 262. On 31 October 1550 Cornelis Floris arranged the surety, stipulated in the contract, before the Antwerp aldermen: SAA, Schepenregisters, no. 239, register WG I, fol. $318 \mathrm{v}$. I am grateful to Robrecht Janssen for drawing my attention to this document.

Huysmans et al. 1996, 96 and 81.

KR 1550, fol. 27 (March 1551); KR 1551, fol. 65V (June 1552); KR 1552, fols. 102r-v (July 1552); KR 1552, fol. 106v-107 (October 1552, 'Betaelt de selve [Jan van Haughen, byldesnyder] van dat hy die steen vanden heylyghen sacramens huysse uwytten scepe heeff helpen loessen, twee daeghen').

Arty 1968, 155 .

Zika 1988; Rubin 1991; Caspers 1992.

For these cults, see Pauli 1620; Historia 1674; Schoutens 1887; Dequeker 2000; Cauchies \& Collet-Lombard 2009; Van Mulder 2016, 102-115 and passim.

Zika 1988; Caspers 1992.

They are never described as sacramentstoren or tourelle eucharistique, which are neologisms, nor as tabernakel, which was a more encompassing term for ornamented niches. Suykerbuyk \& Van Bruaene 2017, 127-128.

The most recent survey of sacrament houses is Timmermann 2009. For the Low Countries, see Maffei 1942; Van Gelder 1972; Lambert 1986; Suykerbuyk \& Van Bruaene 2017.

Welzel 200o.

It is unclear whether the sacrarium was a later addition, as has been claimed by Roggen 1953, 226 , or part of the original altarpiece, as recently argued by Lipińska 2017, 91-97. Mone's Passion altarpiece of 1536-1541, now in Brussels cathedral, might also have contained a central niche for the Eucharist. For both works, see Saintenoy 1931, 39-51 and D'Hainaut-Zveny 2008, 118-121.

A similar assessment in Hedicke 1913, vol. 1, 67-70. Gielis 2014, 82-92.

Fredericq 1922, 595-602.

Decavele 1975, chapter 1; Fühner 2004, 176-185. A similar statement was again uttered in 1529 . Vroom 1981, 298, 316 and 320-321.
Gielis 2015.

Marnef 1996; Marnef 2004.

Duke 1990, 18-23.

See Michalski 2002, as well as the other contributions to that volume. Classic studies include Michalski 1993, esp. 10-11, 52-54 and 75-98, and Wandel 1995.

Eire 1986; Van Bruaene et al. 2016, 6-7.

A recent overview of the events and historiography on the Beeldenstorm with earlier references can be found in Van Bruaene et al. 2016. See also Spicer 2017.

Lamal 2013 .

Toussaert 1963, 597, 6о4-6o5.

'Ob antique pietatis calorem (...) hac infellici tempestate infrigeratum et pene extinctum'.

Vroom 1981, 266-267.

'Propter magnam caristiam, propter doctrinam magistri Martini Lutheri, propter guerras transysulanas, ubi non potuereunt habere cursum. Vroom 1981, 298 and 316.

Vroom 1983, 58-6o.

'Want zindert dat trumoer ende opinie van Lutherus geregneert heeft, soe zijn die aelmoessen der menschen zeere gedeclineert'. Goovaerts 1890, 10-11.

32 Marnef 1996, 83-86.

33 Verhoeven 1992, 160-184.

34 Trio $1993,167-199$ and $346-347$.

35 Trio 2009, 153-154.

36 Duke 1990, 8-10.

37 Goudriaan 1994.

38 Pollmann 2007; Pollmann 2011 .

39 Speetjens 2007, 122-123.

$40 \quad$ Kruisheer 1976.

41 Meuris 1993, 73-74, 80-89, 95-96, 99-100.

42 Franck 2013, 52; Meyers-Reinquin 1969, 216.

43 Leysen 2001-2002, 54, 113-115.

44 De Vries 1984, 271-272 and 280-282; Verhoeven 1992, 7-12.

45 Quote from Dickens 1974, 182. See also Moeller 1962; Ozment 1975.

46 Minnen 2011, vol. 1, 95-98.

47 Decavele 1975, 586-588; Woltjer 1994, 134-135. More recently, see Fühner 2004, 176-185.

48 De Weerd 2016a; De Weerd 2016b.

49 Halkin 1930; Bax 1937; Harsin 1962; Dieterich 1982.

$5^{\circ} \quad$ Van Engen 2008. Compare with Pollmann 2011b.

$5^{1} \quad$ Van Uytven 1974; Peeters 1982; Van Uytven 1995a.

52 Rapp 1971, 317-318. Compare with Lestocquoy 1964, 16o. 
'Doen [1474] begonst onse Lieve Vrouwe opt Stocxken tot Antwerpen in de hooftkercke eerst miraculen te doen, die men doen eerst openbaerde'. Van Havre 1879, 18.

65 Galpern 1974; Duffy 1992. See also Terpstra 2013, 263 .

66 Bogaers 2008; De Weerd 2016a; De Weerd 2016b.

67 Duke 199o, 23-28; Ozment 1971. Compare, however, with Rapp 1971, 320.

68 Walker Bynum 2011, 24-25. See also Camille 1989, 41-44.

69 Examples in Rooijakkers 1996, 32-35.

70 'Refrigescit devotio laicorum et diminuitur debita reverentia sacramentorum'. Quoted from Toussaert 1963, 594 .

\section{Pilgrimage}

Von Campenhausen 1957; Eire 1986; Freedberg 1986, esp. 39-45; Michalski 1993, esp. chapters 1 $\& 2$.

Michalski 1993, 6 and 13-15; Von Campenhausen 1957, 113 and 116.

Calvin 2008, 56. See also Eire 1990.

Zwanepol 2011, 417-419; Rasmussen 2014.

Clemen \& Leitzmann 1932-1934, vol. 1, 392-393.

Clemen \& Leitzmann 1932-1934, vol. 1, 402-404.

See also Eber 2012.

Vogler 1972; Walker 1988.

Eire 1986, 89-9o.

Sluhovsky 1995 .

'Es sein zeychen einis grossen unglaubens ym

volck'. Clemen \& Leitzmann 1932-1934, vol. 1, 4 O2. See also Soergel 2012, 34-46.

Walker 1988, 111-112; Eire 199o, 258-259.
Halkin 1969; Halkin 1971; Van Herwaarden 1974; Eire 1986, 43-44; Van Herwaarden 2007; Nagel 2011, 39-40.

13 Erasmus 1965, 4-7. On the 'theology of localization' and broader Protestant critiques on this principle, see Van der Velden 2000, 199-208.

Erasmus 1965, 285-312, esp. 288-291; Godin 1988. and 340-341 (A Fish Diet, 1526).

In Peregrinatio religionis ergo, for instance, he referred to Antwerp pilgrims and the cult of Onze Lieve Vrouw op 't Stokske in that city. Erasmus 1965, 291 and 309.

Cramer \& Pijper 1903-1914, vol. 1, 151-249.

Cramer \& Pijper 1903-1914, vol. 1, 196.

Cramer \& Pijper 1903-1914, vol. 1, 399-420.

'Merkt haer supersticie die sy tot noch toe gebruyckende zijn daghelicx, want die beelden so langhe als sy inden beeltsnijders winckel zijn, so en connen sy geen miraculen doen, tot der tijt toe datse dese fijne ghesellen ghebrocht hebben in haer hoerachtige kercke, ende die cruycen dewijle si zijn onder de goutsmits handen, so en is daer gheen heilicheyt in, maer alse dese ypocriten die eens gevinghert hebben, dan moetmen die bonet daer voor af nemen ende die knien buyghen, ende sy gaen daer achter bleetende ende crijschende achter haer valsche goden'. Cramer \& Pijper 1903-1914, vol. 1, 416; translation from Moxey 1976-1977, 159.

Cramer \& Pijper 1903-1914, vol. 4, 123-376. See in particular Cramer \& Pijper 1903-1914, vol. 4, 277-295.

'(...) gantz gelogen van munnicken, papen und ander boeven, de mit sulcke schelmery viel geltz gestolen hebben'. Cramer \& Pijper 1903-1914, vol. 4, 289-291 and 293-294.

'Wat wildy daer maken? Geloofdy an houdt ende steen?' Fredericq 1889-19o6, vol. 4, 373.

Mak 1946, 103-104 ('ter waerelt meest zotheyt tooght').

Becker 1994, 22-27; Ubl 2014, 155-167 and 316-319. Haeger 1986, 135-136.

Moxey 1976, 62-70; Becker 1994, 37.

Fredericq 1889-19o6, vol. 4, 338-339, 356-357 and 393.

Molanus 1861, vol. 2, 818-819; Van Uytven 1963, 16, note 39 .

Laurent et al. 1893-1978, vol. 6, 56.

De Brouwer 1961, 133.

Heinderyckx 1853-1855, vol. 3, 6-7. 
Vandamme 1982, 102-103.

Germonprez 2015, 73. For other examples, see Mack Crew 1978, 10; Parker 1988, 75; Arnade 20o8, 151.

Grauwels 1972, 18-19.

Grauwels 1972, 51.

Grauwels 1972, 19 and 22.

See also Sterken 195 .

Hecht 1997, 85 .

Freedberg 1972, 52-54; Jedin 1935, 148-167.

Duffy 2011.

Van den Bundere 1557, 14-28, 172-179; Verdée 2008, 271-272.

Pollmann 2006; Pollmann 2011a.

Freedberg 1972, 72. On these treatises see most recently Jonckheere 2012.

Jedin 1935; Fabre 2013, 45-68; O’Malley 2013.

Waterworth 1848, 233-236. Gilmore Holt 1957-1966, vol. 2, 62-65 provides only a partial translation of the decree. An edition of the original Latin text with a French translation and discussion is provided by Fabre 2013. For the Byzantine image controversy, see Bryer \& Herrin 1977.

Davis-Weyer 1971, 47-49; Norberg 1982, 873-876. See also Hecht 1997, 169 .

Hecht 1997, 224-225.

Gilmore Holt 1957-1966, vol. 2, 65. See also Jedin 1935, 427. Note that Latin decree does not use peregrinatio, which was a consequence of the absence of established terminology to refer to pilgrimages (see Chapter 2). The 1565 Dutch edition nevertheless specified that it concerned pilgrimages: 'Dat ooc de menschen het vieren vanden heyligen, oft pelgrimagie gaen, ende besoecken de heylige reliquien, niet en misbruycken tot overdaet ende dronckenscap (...)'. Ordonnancien 1565 , fol. 235 .

Waterworth 1848, 234.

'Wat die luyden te Leuwe muchten bevaert gaen? Dat beelt van Sint Lenarts weer van eenen noteleer gemaeckt ende Sint Lenarts kroht weer van eenen verckens troech gemaeckt (...) Arme verdoelde menschen weer dat sy daer geloeff op stelden meynende dat dat beelt van Sint Lenart mirakel deede, want alst scheen sweeten, dan weert met olyen bestreecken'. Hansay 1913, 31-33. For the investigations see also Bax 1937, 266-267. Interestingly, the exact same strategy would later be used by Catholic apologists in defense of images. Dekoninck 2013, 15 o.
54 KR 1538, fol. 358v (August 1538, 'dy vrouwe dy voer Sintte Leonart sit').

55 In the 1509 mural paintings in Saint Genevieve's chapel at Zepperen a man called 'Adriaen der Stockhueder' is depicted, i.e. 'Adriaen the surveillant of the offertory box'. See BALaT object no. 7996o. Compare with the visual sources in Chapter 1.

$56 \quad$ KR 1555, fol. 222v (June 1556, 'enen man van te Sinsen in de kercke 4 nachten te waecken').

$57 \quad$ KR 1561, fol. 402 (January 1562); KR 1565, fol. 541 (January 1566); KR 1566, fol. 539 (December 1566); KR 1567, fol. 445 (December 1567).

$5^{8} \quad$ KR 1555, fol. 22 ov (May 1556, 'van een cleet voer Sinte Lenaert te maken').

59 Van Autenboer 1983; Van Autenboer 1985, 258-26o. On the chamber of rhetoric, see also Sacré 1919, 41-44.

6o KR 1542, fol. 242v (July 1542, “[Meester Anthonis de Schilder] heeft inde vanen onsen patroen gemaect (...) Heere Peeter Scutiser vanden vanen te repareren ende de patroen in te setten'); KR 1556, fol. 268v (April 1557, 'Betaelt te Sinsen 7 kinderen van de goude cappe op te houden, de candelaren te dragen ende vieroeck te verpen').

$61 \quad$ KR 1523, fol. 72V (June 1524); KR 1530, fol. 153V (May 1531); KR 1534, fol. 25 (May 1535); KR 1538, fol. 379v (June 1539); KR 1547, fol. 279 (May 1548, 'die pelgrams zeel dair sye tuesschen gaen'). Compare with the yearly procession with the relic of the Holy Blood in Alkmaar, 'in welcke processie gaen menich menschen in linnen cleeren ende in pansijsers, diet theilige bloet gheloeft hebben ende daer doer vertroest syn ende noch hoepen vertroest te worden'. See Rijkenberg 1896, 402.

62 The low figure in the graph for 1538 is to be explained by the fact that only an incomplete draft version of the account has been preserved, in which the revenues for the Whit Monday procession are missing.

63 Minnen 2011, vol. 1, 73 and 77.

64 Dombrecht 2014, 284-287 and 423.

65 KR 1548, fol. 317v ('vier wrouwen die te Sinsen met wasse geseten hebben'). See also KR 1556, fol. 268v (April 1557); KR 1557, fol. 312 (April 1558); KR 1559, fol. 354v (February 156o). Compare with Van der Velden 2000, 249-25o.

66 See for instance KR 1551, fol. 156o (February 1561, 'de kerssen voir Syncte Leonardt'). 
67 'De selve ghiften tooghen oock wat cracht ende macht dat die martelaers hebben, die daer begraven sijn'. Du Val 1566, fol. 71v. See also Molanus 1996, vol. 1, 266-267.

68 KR 1534, fol. 26v (June 1535, '3 yseren geerden met 6 ooghen gemaeckt ende inden muer geslaghen om dyseren bienen aen te hanghen').

$69 \quad$ KR 1556, fols. 265 (January 1557, 'Claes Roesen van enen hulten been te maken') and 272 (June 1557, '[meester Anthonis van Hulleberge] van een hulten been te schilderen geel'). For other examples, see Minnen 2011, vol. 1, 102, as well as Van der Velden 200o, 175-176, 185-187 and 262, who also discusses the process in general.

$70 \quad$ KR 1549, fol. 35ov (August 1549): 'Betaelt van het haernies dat voir Syncte Leonardt hanght schoen te maken'.

71 KR 1540, fol. 206v.

72 First registered in KR 1547, fol. 265v. For his activities in the service of the churchwardens, see for instance KR 1557, fols. 312v-313 (May 1558). See also Van Autenboer 1983, 410, 414, 417 and 423 .

73 KR 1554, fol. 163 (May 1555, 'betaelt 4 vrouwen die metten beeldekens ende met was opten merckt geseeten hebben').

$74 \quad$ KR 1533, fol. 19 o (April 1534); KR 1534, fols. 17V (August 1534, 'Noch betaelt van eenen ijser daermen Sinte Leonart op steeken soude om bielsekens te slaene (...) Noch betaelt den meester van Luydick van Sinte Leonart daer op te steeken'), 19 (October 1534, 'Noch gecocht tot Luydich een lattonen voermen ende een yseren om silveren teekenen te slaene ende die lattonen om loeten te ghieten voer de pelgrems') and 24 (April 1535, 'Noch betaelt tot Bruesel van eenen yser daermen silveren ende cooperen teekenen van Sinte Leonart op slaet voer de pelgrims te Pinxsten').

$75 \quad$ KR 1547, fol. 278 (May 1548); KR 1549, fol. 357V (March 1550).

76 KR 1534, fol. 17 (August 1534, 'teekenen van Sinte Leonart met gelaeskens').

77 Van Loon van de Moosdijk 2004, 103.

78 Van Uytven 1974, 186, table IV; Van Uytven 1995a, 13; Van Uytven et al. 2004, tables 6.5 and 6.7.

79 A similar pattern can be observed at the shrine of Saint Guido in Anderlecht, see the data collected by Roobaert 2004, 2-15. In Wezemaal, on the contrary, the number significantly diminished: Minnen 2011, vol. 1, 68-69 and 94-95. 8o KR 1540, fol. 222v (June 1541, 'vaynkens voer die pilgrims').

81 An early example from Brussels in 1471 is mentioned by Roobaert 200o, 261.

82 Van Heurck 1922, viii-xviii; Thijs 1991, 76-8o.

83 Compare with the observations by Van der Stock 1998, 133-134, 186. See also Freedberg 1991, 124-126.

84 Van der Linden 1958, xviii and 118 gives several early sixteenth-century examples from the County of Flanders.

85 KR 1548, fol. 321; KR 1551, fol. 64V (June 1552); KR 1561, fol. 406 (May 1562, 'vaenkens te stelen ende te pappen').

86 KR 1542, fol. 244 (October and November 1542); KR 1547, fol. 277v (April 1548); KR 1549, fol. 352v (November 1549).

$87 \quad$ KR 1550, fol. 22 (October 1550); KR 156o, fol. 315V (November 156o). He also furnished pennants to the church of Saint Gertrude in Machelen: Roobaert 2004, 20.

88 KR 1551, fol. 62V (April 1552); KR 1552, fol. 115 (April 1553); KR 1555, fol. 220 (May 1556); KR 1556, fol. 254V (July 1556); KR 1557, fols. 303v (August 1557), 309 (January 1558) and 314 (June 1558); KR 1561, fols. 397 (September 1561), 401 (December 1561) and 4O1V (January 1562); KR 1565 , fol. $541 \mathrm{~V}$ (January 1566); KR 1566, fol. 539v (January 1567); KR 1567, fols. 439v (August 1567), 445 (December 1567) and 448v (April 1568); KR 1569, fol. 5 o6 (July 1569); KR 1573, fols. 395 (December 1573) and 400 (May 1574); KR 1577, fol. $475 \mathrm{v}$ (November 1577).

89 See especially Roobaert 2004, with many references.

$90 \quad$ Roobaert 200o, 262-263, 266, 276 and 289.

91 Dombrecht 2014, 286-287. Compare with the data on the confraternity of Our Lady in the Church of Saints Michael and Gudula, and the confraternity of the Holy Sacrament in the Church of Saint Nicholas: Roobaert 2000, 258-268 and 281-286.

92 Sellink \& Silva Maroto 2011, 789-79o.

93 KR 1540, fol. 201; KR 1577, fol. 461. The conversion from halsters to liters is based on Doursther 1840, $35^{6-358 . ~}$

94 KR 1516, fol. 17v (June 1517); KR 1534, fol. 26 (May 1535, 'gecocht te Pinxsten voer die pelgrems een rintspense, een kalffhoot metter leveren, een scaeptshoot ende smout totter soppen'). 
KR 1503, fol. 29 (June 1504, 'biere dat daer gehaelt waert voer die pelgrijme dij voere Sinte Leonart gingen'); KR 1515, fol. 13 (July 1515); KR 1516, fol. $17 \mathrm{~V}$ (June 1517).

KR 1530, fol. 155 (June 1531); KR 1533, fols. 168v and 192V (June 1534), and KR 154O, fol. 213V (July 1540); KR 1549, fol. 359v (June 1550, 'Betaelt aen perper, saffraen, suker ende naeghelen om te Syncsen in die pergroms eerten te doene'). Cooked peas were also provided to pilgrims elsewhere, such as in Amersfoort and Berchem: Thiers 1994, 25; Prims 1949, 105. The conversion from amen to liters is based on Doursther 1840, 158 and 437 .

Woltjer 1962; Woltjer 1968, 383; Duffy 1992.

Woltjer 1994, 89-102 and 134-136; Marnef 1996, 88-9o; Kaplan 1994.

'(...) dicte ecclesie S. Leonardi, que a Christi fidelibus undique confluentibus propter multa miracula, quibus Divus Leonardus in eadem ecclesia S. Leonardi valde clarere dignoscitur'. Bets 1887-1888, vol. 2, 294-295.

'(...) adversus occupatores et devastatores bonorum suorum'. Full text and discussion in Bets 1887-1888, vol. 2, 170-175 and 292-297. See also Pieyns-Rigo 1970, 1128-1129.
Hansay 1913, 31-33.

'Item dy papen goeten smalt op dy hoefden van dy bilderen, dan seede sy dat sy mirakel deden'. Grauwels 1972, 33 .

'Alle die Sancten sijn gaen duycken/ Sy en doen geen mirakel meer'. Mak 1946, 161.

Van Mulder 2016, Appendix 1.

Verhoeven 1985, 109 and 136.

Note that the figure for the 153 os does not include the miracles recorded at the shrine of Bolsward, because of a lack of chronological details.

Bets 1887-1888, vol. 2, 155-165. Early twentiethcentury versions of the story specify that the statue was found by a ploughing peasant: De Cock \& Teirlinck 19o9-1912, vol. 2, 157-158; Hendrickx 1924-1925. On this type of narrative, see Delbeke et al. 2015, esp. 221.

Grauwels 1972, 87 and 92.

Balau 1913-1931, vol. 2, 131.

Wichmans 1632, 457-459.

The earliest account has been erroneously included in RAL, KAB, no. 1075. Subsequent accounts are in RAL, KAB, no. 3367 .
112 RAL, КAB, nos. 1048 and 1075; KR 1566, fol. 529; KR 1569 , fol. 5 O3. His financial status can be judged by the high costs he paid for his wife's funeral (KR 1557, fol. 295v).

113 Grauwels 1972, 87.

114 Wichmans 1632, 458; Gramaye 1968, 133-134.

115 In KR 15343561 stuivers were collected, in KR 1550 3935 stuivers.

116 Minnen 2011, vol. 1, 98, 103-104 and 108.

117 On the cult, see Pauli 1620, 134-147. The original miracle book has not been preserved, but it was published in the later 17 th century: Historia 1674 , 9 .

118 For the miracle collections, see Loërius 1532; Adam 2014, 415-416; Van Mulder 2016, 106-115. On the new chapel and reliquary, see De Bruyn 1870, 167-168; Lefèvre 1956-1957, 34-38 and 62-71; Van Ypersele de Strihou 200o, 6-11 and 76 .

119 In this early period other Augustine cloisters in the Low Countries, including those of Antwerp, Dordrecht, Ghent and Tournai, were strongly influenced by Luther's teachings. See Decavele 1996, 69.

Dequeker 200o, 52-6o; Thøfner 2007, 255-275.

1 Brussels, KBR, Ms. 14896-98, fol. 62 ('des keysers hoff'). Van Mulder 2016, 111. Van den Boogert 1992. But see Reintjens 2013, 152-153. Leemans 1972, 279-281; Damen 2005. The original reliquary has not survived, see Van Ypersele de Strihou 200o, 75-92. Van der Velden 2000, 123, discusses an equally exceptional example of a window donated in 1501-1503 by Philip the Fair to the Brussels Church of Our Lady of the Zavel.

Fühner 2004.

Fredericq 1889-19o6, vol. 5, 243-244; Decavele 199o, 20-25; Gielis 2015, 426 and 442.

129 'Schoender noch devoter processien en was in hondert jaeren te voeren noeyt gesien'. Brussels, KBR, Ms. 14896-98, fol. 62; Van Mulder 2016, 113-114.

130 George 1998, 8.

131 George 1998, 21, no. 15 .

132 Other discussions of this material in Waite 2007, 42-45 and Pollmann 2011a, 52-57.

133 Grauwels 1972, 20 ('nyet dan broot').

134 Grauwels 1972, 46. 
135 Grauwels 1972, 23.

136 Grauwels 1972, 37-38.

137 Grauwels 1972, 27-28.

138 Pleij 1973-1974; Pollmann 2011a, 55.

139 Heiss 1990-1991; Ditchfield 2007, 213; Waite 2007, 40-41, 49 and passim.

140 Waite 2007, 37.

141 Van den Bundere 1557, 22-23, 177-178. Other examples in Brussels, KBR, Ms. 14896-98, fols. 41 (1523) and 42v-43 (1524).

142 Compare with Freist 2009, 215, who referred to the 'confessionalization of public space'.

\section{Parish Liturgy}

Laqua-O'Donnell 2013, 291-294.

Kümin 1997; Bijsterveld 20oo-2001; Bauwens 2015 .

Erasmus 1965, 267-285 (Puerpera), quote on 269-270.

Decavele 1975, 274 and 591.

'Dit misbroit is Gott geheten, kostelic opgesloten, mit monstrantien, lampen, kerssen, unde hogen sacramentzhousen gheeret, onder den beelden in groten processien omgedragen, mit crucen, fanen, trommen, unde allerley gaipspul, ghelijck de Heiden voirhin, mit horen affgoden gedain hebben (...) Summa dat kleine dode broit is op allen orten des pausdoms vur den groten levendigen Gott angebeden'. Cramer \& Pijper 1903-1914, vol. 4, 212.

Wandel 2014 provides detailed discussions of the Eucharistic theologies of the different confessions. Decavele 1990, 20-25.

Decavele 1975, 266 and 589-599; Van Bruaene 2016a, 44-47.

De Coussemaker 1876, vol. 3, 156-157 and 166; Deyon \& Lottin 1981, 182.
SAL, Oud Archief, no. 299, fol. 268.

RAB, Raad van Beroerten, no. 38 , fols. $26 \mathrm{r}-\mathrm{v}$ and 84v; Historie 1569, fols. 240v-241; Acquoy 1873, 42-45; Kumler 2015, 119-121.

Arnade 2008 discusses carnivalesque aspects of the Beeldenstorm.

Beenakker 1971, 25.

RAB, Raad van Beroerten, no. 6, fol. 442.

Enno van Gelder 1925-1942, vol. 2, 237-239;

Russe 1953, quotes on $115^{-118}$. A similar case is documented in Tournai's cathedral of Our Lady in 1554: Arnade 2008, 115.
16 Vander Meersch 1842, 17-19.

17 '(...) en woude nyet gheloven dat dy priesters eynighe macht hedden te consacreeren dat eerwerdich heylich sacrament'. Grauwels 1972, 21-22.

18 '(...) nyet dan broot inden oven gebacken'. Grauwels 1972, 29, 33 (1535), 36 (1536) and 48 (1537).

19 Grauwels 1972, 28. Another example of irreverence in Daris 1887-1891, vol. 3, 410-411. Toussaert 1963, 122-204.

Quote from Falkenburg 2007, 183. In general, see Post 1954, 401 and 405; Kroesen 2006; Falkenburg 2007. On the frequency of communion, see also Van Miert 1921-1922, 112-124.

22 KR 1456, fol. 148v; KR 1468, fol. 13. Elsewhere it was also referred to as 'monnichbroets': Bonenfant \& Frankignoulle 1935, 63.

23 Toussaert 1963, 18o-184; Mols 1964, 407; MeyersReinquin 1969, 210-211. Elsewhere churchwarden accounts distinguish between 'messebroets' and 'sacrament broots': Weale 1874, 9-11.

24 KR 1496, fol. 170 (March 1497); KR 1557, fol. 309 (January 1558); Kumler 2015, 126-128.

25 See for instance resp. KR 1534, fol. 19v (November 1534), KR 149o, fol. 41v (September 149o) and KR 1505, fol. $25 \mathrm{~V}$ (June 15o6). Toussaert 1963, 162 and MeyersReinquin 1969, 208-209 respectively refer to it as 'vin d'ablution' and 'nataalwijn' or 'ablutiewijn'.

26 KR 1555, fol. 206 (July 1555, 'croeskens voer de siecken om te Paesschen vut te drincken').

27 The conversion from quarten to liters is based on Doursther 1840, 158 and 437.

28 Confrontation of a 1497 pouillé (Paquay 19o8, 84) with one from $155^{8}$ (De Ridder 1865, 141-142) reveals an unaltered parochial organization. The 1543 request to abolish the Priory of Val des Écoliers (Chapter 4) might have entailed an extension of Saint Leonard's parish rights, however, as part of the parochial services - including burial - were held in the priory church, see Bets 1887-1888, vol. 2, 170. While Pieyns-Rigo 1970, 1129 maintained that the request did not have any practical consequences, the funeral rights of Saint Leonard's church appear to have been extended in 1556 (KR 1555, fol. 215 (February 1556)). It remains unclear if both events are related. For Zoutleeuw's demographical evolution, see Van Uytven 1995a; Van Uytven 1995b. 
KR 1556, fol. $247 \mathrm{r}-\mathrm{v}$ ('van offer voer den wijn opde tafel'). Compare with KR 1566, fol. 535 (August 1566, 'banckens (...) diemen beesicht als men tOnssen Heer gaet'). See also Brian 2014, 186-188.

Toussaert 1963, 162 claimed that such furniture did not yet exist, and it is lacking in classic overviews such as Reinle 1988 and Bangs 1997. Prims 1939, 119 ('6 dweelen om te Paschen de tafelen mede te dekken daar men den wijn geeft int moenigen van den gemeynen volke'). '(...) dat men generalick ten Sacrament solde gaen, die communiceerbanck setten mit die banck, dair men den wiin aff ontfengt, ende idt bret, dair men die wiinkannen op settet, ende alle desen becleeden mit den cyraet dairtoe behoorende (...)'. Van Veen 1916, 110. Weale 1874, 20.

Toussaert 1963, 175-180 and Meyers-Reinquin 1969, 210 respectively referred to it as 'nataelpennijnck' and 'wijngeld'.

KR 1552, fol. 112 (February 1553); KR 1561, fol. 384; KR 1566, fol. $5^{26 v}$. Compare also with the list of holidays for which wine was bought in KR 1561, fol. 400 (December 1561): 'weyn (...) op Alder Heyligen dach, Kersmisse, Lichtmisse ende ander hoechgheteyen ende lieffve vrouwen dagen'.

'(...) ten minsten jaerlicx te paesscen ten heyligen Sacramente te gaen'. The different sorts of communion are referred to as 'sacramentelyck' and 'gheestelyck'. Ordonnancien 1565 , fols. 112r-v and 114V; Daly 2014.

Vervoort 1552, Chapter 6: 'Hoe wij met berrender liefden sullen dickmael gaen totten heylighen sacramente'. See also Van den Bundere 1557, 132-133.

Meuris 1993, 74-78; Leysen 2001-2002, 57-59. Compare also with Van Miert 1921-1922, 121-123. Paquay 2001, 36.

For Antwerp, see Antwerpsch chronykje 1743, 76 and Wegman 1989, 185. For other examples, see Van Veen 1916, 247-25o; Gysseling 1952, 51; Post 1954, 402-405; Paquay 2001, 36-37; De Loos 2012, 91-93.

RAL, КAB, no. 1033 , fol. $13 \mathrm{v}$.

Grauwen et al. 1996, 183, no. 830; KR 1555, fol. 195v. RAL, KAB, no. 1033, unfoliated, and no. 1043, fols. 18v and 21. For other examples, see Post 1954, 402-405. For a definition of lof ceremonies, see Wegman 1989, 185 .
RAL, KAB, no. 1074 (1520-1533); RAL, KAB, no. 1075 (1537-1544 and 1554).

45 Such as at Tiel in 1540: Van Veen 1916, 249-250.

46 See for instance KR 1533, fol. 168; KR 1547, fol. 28ov; KR 1556, fol. $272 \mathrm{v}$.

47 Roobaert 200o, esp. 299-300, Appendix II.

48 Halkin 1930, 206-208; Ramakers 1996. See also Goudriaan 1994, 74.

49 Joblin 1999, 134-135.

$5^{\circ} \quad$ Erasmus 1965, 307; Eire 1986, 44.

51 Kist 1840, 228-238; Wegman 2005, 181-185.

$5^{2}$ 'In den pauselicken tempelen wurt dat gebet gestoirt mit den onnutten Gregorianschen coirsang'. Cramer \& Pijper 1903-1914, vol. 4, 230-232 and 297-298, quote on 231.

53 For instance Beenakker 1971, 71-72; Scheerder 1974, 82-85; Scheerder 2016, 103-116. In general, see Bangs 1997, 83-94.

54 '(...) chargé davoir avecq aultres pillé et sacagé en leglise Saint Brixe, et meisme davoir happé, abbatu et brisé les orghues dicelle eglise, disant quon avoit faict assez danser dieu des musettes'. RAB, Raad van Beroerten, no. 6 , fol. $43 \mathrm{v}-44$.

55 Kronenberg 1948, 44, 129-130.

56 Oettinger 2001.

57 Mincoff-Marriage 1922.

$5^{8}$ 'Ende es die pastoor inde kercke comende ter stondt opte preeckstoel gegaen sonder stole ofte coorcleet. Ende worde daer duytsche psalmen gesongen ende die pastoor dede voorts alsoe zijn sermoen'. RAB, Raad van Beroerten, no. 115, fol. 48 .

59 Parker 1988, 73.

6o Mack Crew 1978, 8; Arnade 20o8, 98 and 129.

61 '(...) qui ont tousjours servy d'advertence et de mot du guet en toutes leurs entreprinses'. Henne 186o-1861, vol. 1, 177.

$62 \quad$ Freedberg 1972, 111.

63 '(...) zynghende openbaerlijc de verboden psalmen in scandale van eenen yeghelicken', and 'vendu pseaulmes et livres reprouvez'. RAB, Raad van Beroerten, no. 6, resp. fols. 266 and 277.

64 'Ghi wiltse al tsamen doen zingen alzo (...) coeien loyen, scapen bleeten (...) De ceremonien der kercke, den sanc in de tempelen, de cirage, verwecken den mensche tot devotien (...)'. Van den Bundere 1557, 163 .

65 See Beghein 2014, 32-33.

66 Oettinger 2001, 55-6o discusses pre-Reformation devotional songs in the vernacular. 
67 Bouckaert \& Schreurs 1998, 35; Beghein 2014, 53. See also the example in Thelen 2015b, 75-8o.

68 Beghein 2014, 27-32.

69 Brussels, КвR, Ms. 21131 and 21132.

$70 \quad$ First mentioned in KR 1547, fol. 274

(November 1547, 'Meester Jan Jelviedoy met die zanghers van Diest, uwt bevel van borghenmeesters gegeven'). See also KR 1548, fol. 311 ('Ghegeven Ghielen van Doen met consente van boergemesters van in Sinte Lenaert dage dy messe helpen te singen') and KR 155o, fol. 24 (December 1550, 'meester Jan de sangmeester met die sangher van Synctruyden'). The accounts suggest this zangmeester was a certain Jan Ghielen van Doen, who returned yearly throughout the 154 os and 155os. Van Autenboer 1983 , 411, note 8 referred to one unique but similar entry in the civic accounts of 1536 , when singers from Sint-Truiden came over on Saint Leonard's day.

71 Vente 1960-1961, 39; Grauwels 1972, 49; Wegman $1989,175^{-176}, 194-195$, note 38 and 245 ; Paquay 2001, 77, note 149. In 1532 some singers from Diest also took part in the Whit Monday procession at Zoutleeuw. See Van Autenboer 1983, 414.

KR 1557, fol. 304 (September 1557, 'den sangers van op Sinte Lenaerts dach de meesse ende loff te singen'). Wegman 1989, 185; Trio \& Haggh 1994, 72-78.

74 KR 1548, fol. 315 ('Ghegeven meester Jan van Doen om dobbel pampier te copen om enen sanboeck te maken'); KR 1549, fols. 356v (January 1550, 'Betaelt Mr. Jan de Sangmeester van een boeck pampiers te coepen in grote forme om sanck inne te scryven') and 362 (June 155o, 'Betaelt Meester Jan die Sangmeester van eenen boeck van duyskant in groete forme'). See also KR 1550, fol. 25v (January 1551) and KR 1554, fol. 149 (September 1554, 'den sangers van die misse in discant te singen op Sinte Leonarts dach').

Thelen $2015 \mathrm{~b}, 87$.

Grauwels 1972, 49 and 192.

Compare with Kavaler 200o, 238-239.

RAL, KAB, box 982 , no. 1281.

First mention KR 1559, fol. 347 (September 1559).

In the late fifteenth-century graduals Saint

Cecilia occurs in the rubrics, but not in an

individual chant: Brussels, КBR, Ms. 21132,

Sanctorale, fol. $66 \mathrm{v}$.

8 o KR 1565, fol. 533 (July 1565); KR 1567, fol. 438v

(July 1567); KR 1569, fol. 508v (September 1569).

Compare with KR 1549, fol. 362 (June 1550).
KR 1555, fol. 213 (December 1555, 'enen sankboeck'); KR 1561, fol. 40ov (December 1561, 'eenen sancboeck voer die sanghers').

KR 1559, fol. 348 (September 1559); Beghein 2014, 100.

83 KR 1554, fol. 158v (February 1555).

84 See for instance KR 1533, fol. 192v (June 1534) versus KR 1487, fol. 303v (June 1488) and KR 1506, fol. 22 (March 1507).

85 KR 1503, fols. 20v-21 (October 1503).

86 Most of the relevant sources and identifications have been published by Vente 1956, 164-165.

$87 \quad$ KR 1473, fol. 122 (September 1473); KR 1487, fols. 298 (July 1487) and 3oiv-303v (FebruaryJune 1488); Vente 1956, 164 and 220-221, note 2.

88 KR 1500, fols. $15 \mathrm{v}$ (October 1500 ), $16 \mathrm{v}$ (December 1500) and 17 (January 1501); KR 1503, fol. 18 (August 1503); KR 1505, fols. 15 (September 1505) and 21v (March 1506); KR 1506, fol. 22 (March 1507); KR 15०8, fol. 292V (May 1509); Vente 1956, 164; Vente 1958, 21.

$89 \quad$ KR 1525, fols. 119 (September 1525) and $120 \mathrm{~V}$ (December 1525); KR 1533, fols. 183v (January 1534), 185-186 (February 1534) and 188-19o (April 1534). See also Vente 1956, 143.

9o KR 1554, fols. 154-159v (December 1554February 1555) and 169 (June 1555).

$91 \quad$ KR 1557, fol. 304V (September 1557), 308v (January 1558) and 309v (February 1558); KR 1559, fols. 346 (August 1559), 347 (September 1559), 349 (October 1559), 351v-352v (December 1559), 357 (April 1560), 359v (June 156o); Vente 1958, 9o. Compare with the founding of the prestigious Saint Cecilia confraternity in Evreux (Normandy) in 1571 and the Congregazione de' musici di Roma in her honor in 1585: Husk 1857, 113-115.

Minnen 2011, vol. 1, 98-10o.

94 Van Durme 1964, 202, no. 913; Fischer 1975, 12. Other versions are kept in the churches of Saint Hilarius in Bierbeek and Saint Eustace in Zichem, for instance. See resp. BALaT nos. 32354 and 26634.

95 Rice 2007.

96 Beghein 2014, esp. 93 and 185-186.

\section{Patronage}

1

Parts of this chapter are based on Suykerbuyk 2017 and Suykerbuyk \& Van Bruaene 2017.

2 Quoted from Lundin 2012, 175-176.

3 Lundin 2012, 172-177. 
Schleif 1990, 235; Van Bueren 2005, 20. Such an integrated approach has recently been proposed by Van Bueren et al. 2011, 220-221. On patronage, see Martens 1992; Flora 2012; Hourihane 2013.

Pawlak 2011; Lipińska 2013.

See for instance Hourihane 2013, xx-xxi.

Burgess 2002, 314-315, 326; Reitemeier 2005, 121-122.

Brine 2015.

De Ridder 19o8, 58-61: 'het epithaphium Kempeneers', 'het epithaphium Mr. Jan Bollen', 'Frans Minten epitaphium', 'tepithaphiom Kerckhoffs', 'tepithaphiom Gilis Vreven' and 'het epithaphium Egidii Hugeni'.

KR 1452, fol. 10; KR 1503, fol. 26 (March 1504, 'vinsteren daer die Gruyters wapenen inne staen'). On the De Gruytere family, see Bets 1887-1888, vol. 1, 104-105.

KR 148o, fol. 29v (April 1481); KR 1481, fol. 63v (October 1481, 'dy ghelasen vinstere metten wapenen van dy van Liefkenrode'); RAL, KAB, no. 1043 , fol. $8 \mathrm{v}$.

'Hier [leyt begraven] M. Henrick van Strijroeij, hy sterf int jaer $\mathrm{xv}^{\mathrm{C}}$ ende $\mathrm{lxv}$ den xii dach Meij ende joeffrouwe Margriet Speken sy sterf int jaer $\mathrm{xv}^{\mathrm{C}}$ lxi den $\mathrm{x}$ augustus. Bidt voer $\mathrm{h}[\mathrm{en}]$ siele [om] Godts wille'. The last part of the inscription is not legible.

KR 156o, fol. 308 .

KR 1565 , fols. 409 and $532 \mathrm{v}$.

Compare with the Virgo lactans and the Virgin and Child with Saint Anne (both in Brussels, Royal Museums of Art and History, resp. BALaT object nos. 20048978 and 11016576 ) and the Penitent Saint Jerome in Liège (Musée Curtius, BALaT object no. 10133480). On the technique and its use, see Helbig 1945 and Brauneck 1978, 205-237. Grauwen et al. 1996, 317.

'Domino et Magistro Henrico Spieken, ecclesie huius collegiate canonico et decano, anno 1555 21 octobris defuncto, heredes memorie ergo posuerunt Willem Spieken, obiit anno [15]70 18 Augusti, Joncfro Mari Helspighels, obiit anno [15]97 4 Ianuwarii, Iofrouw Anna Copis, obiit anno 160413 decembris'.

Grauwen et al. 1996, 236 and 265.
2 KR 1572, fol. 527V. A genealogy is included in Brussels, KBR, Ms. II 1517, fols. $47-52$.

The name of their daughter-in-law Anna Copis seems to have been added only later on. On the epitaph, see also Rousseau 189o-1891, 448-451, and Steppe 1971, 632-636.

Compare with Brine 2015, 32 and 50-51. RAL, KAB, no. 1076, unfoliated.

'Tuam crucem adoramus Domine/ tuam gloriosam recolimus passionem/ qui passus es pro nobis, miserere nobis'. Cantus Manuscript Database ID oo6o46a.

27 RAL, KAB, no. 1076 , fol. 5 .

28 Grauwen et al. 1996, 289, no. 1314. Compare with RAL, KAB, no. 1033 (unfoliated), KR 1561, fol. 372, and KR 1559, fol. $338 \mathrm{v}$.

29 Grauwen et al. 1996, 116 (no. 529) and 232-233 (no. 1055).

$30 \quad$ KR 1520 , fols. $18 \mathrm{r}-\mathrm{v}$ (December 1520 \& January 1521) and 2ov (April 1521). In September $15^{23}$ mention is made of a consecration, but the accounts do not specify which altar: KR 1523, fol. 67v (September 1523).

$31 \quad$ KR 1533, fols. 168, 177 and 193 (June 1534).

32 KR 1534, fols. 4V, 2ov-21 (December 1534), 21V-22 (January 1535), 24 (April 1535) and 27V (June 1535).

33 KR 1547, fol. 268 ('heer Handrick Aussems heeft gegeven totten aff sluyten van Syncte Peeters coer $\left.9 \mathrm{Kg}^{\prime}\right)$.

34 KR 1547, fols. 26ov, 274 and 275 (November 1547), 276v (January 1548), 282v and 283v (July 1548, 'Claes Roossen van dat antyckx werck dat boven Syncte Peeters coer affsluytten staet').

35 Bangs 1997, 64-65.

36 Zemon Davis 1974, 327-328; Schleif 1990, 232-234; Duffy 1992, 139; Speetjens 2011, 200.

37 Reusens 1866, 12; Bets 1887-1888, vol. 2, 262264 , note 2 . On the benefice of plebanus, see Bijsterveld 1993, 96.

$38 \quad$ KR 1565, fol. 410; De Ridder 19o8, 61.

39 Grauwen et al. 1996, 293, no. 1335.

40 Document published by Bets 1887-1888, vol. 2, 35, note 2. Compare with KR 1565 , fol. $409 v$.

41 KR 1565, fols. 544-549 (March-June 1566), KR 1566 , fols. $533 \mathrm{v}-545$ (July 1566 -June 1567 ).

42 Bets $1887-1888$, vol. 2, 38 stated that a part of the library of Saint Leonard's church went to the Royal Library in Brussels, but of all the publications on Van Haugen's list none of the copies preserved there bears witness to a 
Zoutleeuw provenance. Contrary to the church's manuscripts, no print books from Zoutleeuw are recorded in the library's registers of acquisitions. Müller 2oo1; Maihold 2001.

Quoted from Ditchfield 1995, 124-125.

Frymire 2010, 293-296, quote on 293.

Mack Crew 1978, 5-8.

'Libros sequentes nominatos relinquo eidem

fabrice in usum cujusquumque ecclesiaste ac litterarum sacrarum in nostro oppido studiosi'. Bets 1887-1888, vol. 2, 35, note 2 .

See for instance KR 1456, fol. 148

(November 1456), and KR 1463, fol. 269

(April 1464). For the use of the library, see Bets 1887-1888, vol. 1, 45, note 1; Gramaye 1968, 132. On preaching in general, see Van Herwaarden 1982, 192.

Compare with the emphasis on sermons in visitation reports: Toebak 1992, 127-128.

'Aussi at le prédicateur de la court, et celluy de saincte Goule, auquel l'on at miz ung billet affin qu'il se gardît de tant parler de Calvin; mais il ne le lesse pour cela, et tous ceulx que preschent en ceste ville se sont fort bien acquitez à confirmer le peuple'. Poullet 1877-1896, vol. 1, 201.

The ideas discussed in this paragraph were first published in Suykerbuyk 2017.

The first such entry is in KR 1559, fol. 341v. RAL, KAB, no. 1000, 101-107; Wauters 1892, 538. Recounted in Bets 1887-1888, vol. 2, 262 and 268, note 1, and Wilmet 1924, 12, but see Van den Bossche 1996, vol. 3, $35^{2}$ and Verleysen 2003. Wilmet 1938, vol. 1, 167 also mentions the story of the church's carillon as a gift from Van Wilre, which is not documented either.

On the family, see De Troostemberg 1912 and Van den Bossche 1996.

Van den Bossche 1996, vol. 1, 14-15, and vol. 3, 366-387.

Van den Bossche 1996, vol. 3, 332-333 and 337. RAL, SL, resp. nos. 3012, fol. 166, and 3013, fol. 78; Van den Bossche 1996, vol. 3, 33 .

On their residence, see RAB, Familiearchief De Troostembergh, no. 24, and RAL, SL, no. 3037, fol. 87. On his birthplace see Van den Bossche 1996, vol. 3, 348 .

60 Original deed of gift in RAL, KAB, box 981, no. 1213, published by Bets 1887-1888, vol. 2, 131-132, note 1.

Transcript of the contract in RAL, SL, no. 3030, fol. 6v. On Oten (also spelled Oyen, Oeyen, Oeen and Oyeten), see Van Dievoet 2000, 123-124.
Original foundation charter in RAL, KAB, box 982 , no. 1258 .

63 Her date of death is recorded on the couple's gravestone (Chapter 3). Compare with KR 1554, fol. 142 .

64 The original foundation charters are all in RAL, КАВ, box 982, resp. nos. 1261,1268 and 1281 .

65 The present whereabouts of the testament are unknown, but is published in full by Bets 1887-1888, vol. 2, 262-264, note 2. Tafereel and epitaphium are used interchangeably to refer to epitaphs, see for instance KR 1597 , fol. 99. Compare with Brine 2015, 7-9.

66 Transcript of the contract in RAL, SL, no. 3037, fols. 87 r-v. See also Steppe 1962, cat. T/21. On Van den Kerckhoven, see Cat. Brussels 1979, 76-77.

67 Wauters 1892, 531.

68 De Ridder 1909, 146.

69 The fact that none of their acquisitions are referred to in the churchwardens' accounts suggests that they were donated rather than bought, although it should be mentioned that KR 1553 is missing. On foundation charters, see Martens 2005, 359. Wilmet 1924, 10 was the first to suggest that both Aertsen triptychs were donated by van Wilre. This was accepted by Genaille 1954, 282 and 285; Kreidl 1972, 82-83, note 98 ; Buchan 1975, 108; and Van de Velde 1975, vol. 1, 228-231, who also included Floris' Triptych with the seven effusions of the blood of Christ. First attributed to Aertsen by Michel 1923. An attribution to his workshop seems justified, see Kloek 1989a, 6-9, 15-16 and 20-21. An autograph preparatory drawing of the left outer wing depicting Saint Martin is preserved in Munich (Staatliche Graphische Sammlung, inv. 1949:32): Cat. Munich 1989, 9-10, and Kloek 1989b, cat. A9. Quality marks confirm the triptychs' Antwerp origins: Boreel \& Van Zon-Christoffels 1989, 170.

71 KR 1555, fols. 219v-222 (May and June 1556), and KR 1556, fols. 262v-264 (December and January 1557). Schuler 1992, 24.

73 '(...) sess teekenen ende figueren vander bloetstortingen ons lief heeren ende opden capruyn de sevenste bloetstortinge al in rondeelen nae vuytwijsen die patroonen die hij daer af ontfangen heeft'. RAL, SL, no. 3037, fols. $87 \mathrm{r}-\mathrm{v}$.

74 As the iconography had its basis in religious theater and devotional literature, most iconographic examples are in print: Braunfels 
et al. 1968-1976, vol. 1, 311; Veldman 1986, 267. No other contemporary examples are known in painting. Van de Velde 1975, vol. 1, 228-233; Wouk 2018, $315^{-323}$. It is unclear on which altar it was originally installed, but possibly it decorated that of the Eucharist, with which the themes of the Blood of Christ, death and resurrection are consistent. Work on an unspecified altar next to the sacrament house was done in August 1554. See KR 1554, fol. 147. For the hypothetical shift of the commission from Aertsen to Floris, see Suykerbuyk 2017, 55 .

KR 1557, fol. 307 (November 1557); KR 1565, fol. 540v (December 1565); Van de Velde 1975, vol. 1, 265-268; Suykerbuyk 2O2O, 50-54.

KR 1551, fol. 65V (June 1552, 'sydtsel voir Heylych Sacramenhuys'); KR 1552, fols. 102-104 (July and August 1552), 106-107v (October 1552, 'een metalen lampe meten candelaren soe die voir theylycht sacramens huys hanckt'), 113-114V (March and April 1553), 118v-120v (June 1553), and KR 1555, 216 (March 1556). The thuyn is first mentioned in March 1555, see KR 1554, fol. 161. Its maker remains unknown and it is unclear whether or not it was donated by van Wilre, see Suykerbuyk 2017, 56-57.

(May 1566); KR 1569, fol. 5o6v (July 1569); Van de Velde 1975, vol. 1, 328-330; Wouk 2018, 320-322; Suykerbuyk 2020, 54, 6 o. KR 1549, fol. 362 (June 1550), and KR 1554, fol. 164 (June 1555).

For an elaborate discussion of the project's social aspect, see Suykerbuyk 2017, 64-71.

81 As stipulated in his testament of 10 December 1545 (RAB, Familiearchief De Troostembergh, no. 24).

Vroom 1981, 275; Van Bueren 2005, 17; Timmermans 2008, 214-215 and 26o. A highly comparable example is discussed in Bogaers 2005, 203-205.

Contamine 1998, 100. The concept of 'last of the line memorials' comes from Gittos 2002, 144-145. I am grateful to Frederik Buylaert for drawing my attention to it.

87 Timmermann 2oog, 325-327.
Knipping 1939, vol. 2, 49 and 55; Tixier 2014, 237-242.

89 Compare with Pollmann 2013, 169.

9o The central thesis of the following paragraph was first proposed in Suykerbuyk 2017, and was further elaborated in Suykerbuyk \& Van Bruaene 2017.

91 Duverger \& Onghena 1954; Thijs 199o; Binski \& Black 2003; Muller 2008; Muller 2016. Spicer 2013; Jonckheere 2012, 45-78.

\section{Laven 2006.}

O’Malley 2000.

Compare with Spiertz 1986, $5^{8 .}$

Hall 2013, 3-6.

Compare with Dieterich 1982, who referred to an 'active and pious laity', and Laven 2006.

Weisbach 1921, recently confirmed by Lepage 2013 . Pevsner 1925. See also O'Malley 200o, 35 and 183, note 55 .

For Italy, see Steen Hansen 2004; Nagel 2005; Nagel 2011.

Jonckheere 2013.

Van Eck 2012, 84.

Tacke 2008. Compare with Nagel 2005.

Duke 1990, 18-23.

Decavele 1975, 32; De Win 2003, 159-16o.

Rijkenberg 1896, 339-340 and 398-399 ('dat vaste starcke geloef').

07 Strijroy s.d., quote on fol. 3 v. It was printed between 1557 and 1563, see Axters 1933, 123-125. Other examples are Vervoort $155^{2}$ and Van den Bundere 1557, 131-149.

108 For instance Hessels 1563.

109 Klauser 1969, 137; Tixier 2014, 237-257.

110 Van Duinen 1997, 67-74.

111 Timmermann 2009, 321 and 342; Van Bruaene $2016 a$.

112 Cramer \& Pijper 1903-1914, vol. 1, 486 and 522-523 (Micronius) and vol. 4, 212 (Veluanus).

113 Bloccius \& Pieters 1567, 62 ('De lxxv ketterije is dat de ketters knielen voor een (...) doof Sacrament-huysken'); Van Marnix van Sint Aldegonde 1868, vol. 2, 35 ('de macht noch niet en hadden, om schoone costelijcke ciborien, oft monstrancien ende Sacrament-huyskens te maken'). Other examples in Van Bruaene 2016a, 44-51.

114 Timmermann 2009, 324.

115 To the list of sacrament houses in Suykerbuyk \& Van Bruaene 2017, 147-149 and 150, note 31 can 
be added the example in the Brussels Hospital of Saint Peter (Passchier Borman, 1528-1531), in Berchem's church of Saint Willibrord (Franchois de Roose, 1555), in Borgloon's church of Saint Odolphus (design by Laurens Heroudt, 15571558), in the church of Koudekerke in Zeeland (Henrick Lenaerts, 1558), and in Varsenare's church of Saint Maurice (Ambrosius van Cattenbrouck, 156o-1561). See resp. Bonenfant \& Frankignoulle 1935, 42-43 and 45; Prims 1949, 107 and 132-133; Peeters 1984; SAA, Certificatieboek 13, fol. 349v; Parmentier 1948, 88, note 62.

116 Suykerbuyk \& Van Bruaene 2017, 128-13o.

117 For Diest, see Raymaekers $1857,47-49$, and Bonenfant \& Frankignoulle 1935, 65-67. For Bourbourg, see De Coussemaker 1871. For Breda, see Paquay 2006, 154 and 193-194, note 181. Compare with Mol 1986; Craig \& Litzenberger 1993.

118 For Ghent, see De Smidt 1971, esp. 9-10. For Heverlee, see Smeyers 1986-1987. For Gistel, see Parmentier 1948, 56-58, and Lambert 1986, 19-24. These and other examples are amply discussed in Suykerbuyk \& Van Bruaene 2017.

119 Maffei 1942, 116-117; Suykerbuyk \& Van Bruaene 2017, 137 .

120 KR 1469, fols. 42-46v (July 1469-June 1470). The attribution was first proposed by Hulin de Loo 1913 and subsequently accepted by Destrée 1923 and Roggen \& Withof 1944, 166. De Layens' heightened presence in Zoutleeuw in comparison to other years is an important argument in favor of the hypothesis. Engelen 1993, 135-139 and Timmermann 2009, 114, note 84 refuted the attribution without further argument. See resp. Maere 1946, 346-348, and Van Even 1877,412 . See also Kavaler 200o, 233; Kavaler 2012, $10-11$.

122 KR 1552, fol. 97v.

123 Van den Boogert 1992; De Jonge 2010; Jonckheere 2012, 240-242.

Van Duinen 1997; Glover 2017. Compare with the political and religious claims in Floris' Tournai rood loft: Kavaler 2006.

Van der Laarse 2011; Woollett 2012, 18. Suykerbuyk \& Van Bruaene 2017, 130-133. An in-depth study of the drawing of the sacrament house of the Abbey of the Dunes is in preparation, in collaboration with Jan Van Acker and Alexander Lehouck.
Lansens 1863, 458-459 and 529-531; Suykerbuyk \& Van Bruaene 2017, 135-136. 
Auctor mundana fabrica hic concluditur intus./ Flecte genu supplex, numina sancta colens./ Non hanc quis celebri Salomonis conferat aedi,/ Non umbras, verum sed capit ipsa Deum'. Sweertius 1613, 151-152; Sanderus 1659, 76.

151 Hall 2013, 16.

152 Gielis 2010.

153 Van Uytven 1963.

154 Suykerbuyk \& Van Bruaene 2017, 142-145.

155 Examples in Suykerbuyk \& Van Bruaene 2017, 147. Compare with Van der Velden 200o, 237-238 and Herremans 2009, 35.

156 RAL, SL, no. 3033, fol. 2 ('behoudelyck dat myn joncker oft zyn huysvrouwe daer aen nyet en willen gecontrefeyt zyn'). For a discussion of the original placement of the stone, see Suykerbuyk 2017, 63-64.

157 Van Campene 1870, 17 ('daer vooren hij [Van Cuelsbrouck] knielende ghemaeckt es, ende lichter vooren begraven').

$15^{8}$ Compare with Schleif 1990, 40-45; Duffy 1992, 329-331; Heinz 2012, 322-323.

159 An earlier example is the sacrament house commissioned from Matheus II Keldermans in 1506 by Abbot Gerard vander Scaeft for the Abbey of Averbode. See Lefèvre 1927, 22-23. This and other examples in De Coussemaker 1876, vol. 3, 154, 156-157 and 166.

161 Van Herwaarden 1982, 192.

162 KR 1559, fol. 341v. Compare with Henne 186o1861, vol. 1, 172-173.

163 Consecrations often took place on significant holidays, see Germonprez 2012, 28o. The deadlines for the delivery of the monstrance and the sacrament house were respectively Pentecost 1548 and $155^{2}$, see RAL, SL, no. 303o, fol. $6 \mathrm{v}$ and no. 3033 , fols. 2r-v. Saint Erasmus' altar was consecrated in May 1556: KR 1555, fol. 220. In that year Pentecost fell on 24 May.

164 Buylaert et al. 2014; De Weerd 2016b. On the Protestant side, too, the nobility was called upon to defend 'genuine' Christianity, as is exemplified by Luther's An den christlichen Adel.

165 The foundation charters for the daily Mass at Saint Erasmus' altar and for the sermons: RAL, КAB, Box 982, nos. 1261 and 1268 ('tot vermeerderinge des dienst Goids ende gemeyne welvaerts'). 
Excellent overviews in Woltjer 1994 and Marnef 1999 .

Van Nierop 1991.

Poullet 1877-1896, vol. 1, 201-202; Lamal 2013. Mack Crew 1978.

A detailed chronological overview is provided by Scheerder 1974. See also Duke \& Kolff 1969; Backhouse 1971; Deyon \& Lottin 1981; Scheerder 2016.

Kuttner 1949. Critiques by Leblanc 1951 and Roelink 1964.

Van der Wee 1969.

Compare with Van Nierop 1995, 218.

Arnade 2008.

Zemon Davis 1973; Holt 1993.

Freedberg 1972.

Michalski 1993, 86.

Suykerbuyk 2016.

Compare with the data in De Vries 1984, 271-272 and 28o-281.

'Je ne puis (...) sortir de ceste ville que l'on tient close, qu'est cause que je n'ay moien de faire si ample advertence comme je polroie faire estant à Brucelles: mais le dangier y est trop grand (...) L'on tient icy assez bon ordre et grand guest: mais je craindz que, à la longue, les bourgeois se fascheront'. Poullet 1877-1896, vol. 1, 438 .

'(...) le contentement qu'elle prend de veoir les bons offices et debvoirs que ses bons et loyaulx subiectz font pour eulx conserver et maintenir en leur ancienne devotion tant au regard de la religion que pour service de Sa Majesté.' RAв, Audiëntie, no. 244/2 (no. 126), partially published in Enno van Gelder 1925-1942, vol. 3, 62.

Suykerbuyk 2016, 18-19.

Duke \& Kolff 1969, 322-323. See also the remarks in Roelink 1964, 53 and 70, and Scheerder 1974, 18 and 114 .

Arnade 2008, 125-165.

Scribner 1976, 241.

Lamal 2013, 75-76.

Battistini 1949, 267. The date of 2 August 1566, suggested by Battistini, is evidently wrong, since the letter mentions the destruction suffered in Antwerp, which only started on 20 August.

This is discussed in detail in Suykerbuyk 2016, 21-33. SAL, Oud Archief, no. 299, fols. 250-256.

Such as Bruges, Diksmuide and Hoorn. RAB, Raad van Beroerten, respectively no. 64 , fol. 205 ; no. 55 , fol. 53 ; no. 109 , fol. 362 .
SAB, no. 1724, fol. $99 \mathrm{v}$.

SAL, Oud Archief, no. 299, fol. 254; Battistini 1949, 272-273; Poulet 1877-1896, vol. 1, 432 and 440.

'Et estant fort étrange de veoir en ladite église harquebusiers à crocq et grand nombre de sauldars armez, tellement que à grand peine et difficulté pouvoit-on avoir accèz en ladite église, sinon par estroict passage et l'ung après l'autre'. Verheyden 1954, 31-32. On the re-opening of the church, see De Saint-Genois 1861, 22, and Poullet 1877-1896, vol. 1, 448 and 451 .

SAB, no. 1724, fol. 106; Hoynck van Papendrecht 1743, vol. 2, 377; Poullet 1877-1896, vol. 1, 462. Suykerbuyk 2016, 26-28.

SAL, Oud Archief, no. 299, fols. 258v-262 and 264. Compare with Battistini, 1949, 274; Molanus 1861, vol. 1, 442 and vol. 2, 885; Enno van Gelder 1925-1942, vol. 1, 159 .

RAB, Raad van Beroerten, no. 55, fols. 110-111; Scheerder 1951, 300; Backhouse 1971, 82-83 and 100.

RAB, Raad van Beroerten, no. 109, fols. 363-365. Other examples in Scheerder 1974, 20-21, 35 and 51; Verheyden 1954, 5 and 24; Duplessis 1991, 210; Pollmann 2006, 95 .

Duke \& Kolff 1969, 324; Scheerder 1974, 58-59, 109-110.

Van Uytven 1963. For Brussels, see RAB, Raad van Beroerten, no. 38, esp. fols. 14, 15, 16, 17v, $42,73 \mathrm{~V}$ and $85 \mathrm{v}$, and Marnef 1984, 57-61. Other well-documented examples include Lille and Bruges: Willems-Closset 1970; Backhouse 1971, 64; Dewitte 1982, 39; Vandamme 1982, 107.

Partially discussed in Scheerder 1951, 299-300; Backhouse 1971, 99-100; Scheerder 1974, 27. See the excerpts of the 1566-1567 churchwarden accounts published by Weale $1874,32-33$. RAB, Raad van Beroerten, no. 55 , esp. fols $49 \mathrm{v}-52 \mathrm{~V}$ and 58-62; Weale 1874, 13 and 138-142. 'Les villes du pays d'Arthois, Namur et Luxembourg demeurarent tousjours constantes en la religion catholicque'. Henne 186o-1861, vol. 1, 185-186. Compare with Enno van Gelder 1925-1942, vol. 1, $15^{1}$ and 162; Poullet 1877-1896, vol. 1, 457-458; Wauters 1858, 345-346.

Parker 1988, 73-74; Scheerder 2016, 54-55; Mack Crew 1978, 9 .

'(...) beaucop de marchantz d'Anvers et de Tournay infectéz d'hérésie que font beaucop de maulx (...) menassent d'exterminer tous 
les ecclésiasticques et les massacrer'. Poullet 1877-1896, vol. 1, 374 .

Daris 1887-1891, vol. 3, 40o; Hansay 1931, 226-227; Venner 1989, 101.

Poullet 1877-1896, vol. 1, 380. Bets 1887-1888, vol. 1,201 erroneously referred to this source as the reason why Zoutleeuw escaped the Beeldenstorm which would only escalate weeks later.

RAL, SL, no. $36 \circ 8$, Account of 1566, unfoliated ('eenen brieff ghedraghen tot Diest vande borghmeesters om tijdinghe te weeten vanden gueus').

KR 1566, fols. 539 (December 1566), 543-544 (May 1567) and 545 (June 1567).

Hansay 1932; Venner 1989.

RAL, SL, no. 36o8, Account of 1567, unfoliated. DuPlessis 1991, esp. 313 .

Scribner 1976, 240-241.

'Cives hoc commendat, quod nemo umquam his iniquis temporibus nomine haereseos vel suspectus fuerit'. Gramaye 1968, 13o. No individuals from Zoutleeuw are included in Verheyden 1961.

Van der Eycken 1976, 26-27.

Minnen 2011, vol. 1, 108-109.

'Ende aengaenden dengenen, die souden syn geweest als hoeffden oft promoteurs van het beroven en sacageren van de kercken, enz. adverteren wy uwe Excell. dat wy daer aff nyet en weten, als saeken die binnen dese stadt nyet gebeurt en syn. God hebbe loff!' Deracourt 1953, 127.

64 '(...) als tot een teeken datze zich aan de Pausselijke kerke verbonden hielden, en tegens de Geuzen kanten wilden'. Brandt 1663, 361-362. For the Geuzen medals, see Parker 1988, 72. Poullet 1877-1896, vol. 1, 453; Geevers 2008, $23^{-25}, 100,135$ and $165^{-168 .}$

Piot 1859-186o, 29-42, and Bets 1887-1888, vol. 1, 202-228. Compare with Wezemaal: Minnen 2011, vol. 1, 131-140. In general, see Toebak 1991.

For instance KR 1569, fols. 491v-492 ('voer syn groete schade vanden gueyens').

On these invasions see Parker 1988, resp. 110-111 and 140. On Zoutleeuw in particluar, see also Battistini 1949, $35^{8}$ and 36 o.

See the data provided by Piot 1859-186o, 40-41; Cosemans 1936, 343; Van Uytven 1995a, 12-14. Compare also with the observations by Gramaye 1968, 127 .
70 After 1585 the ecclesiastical authorities were confronted with gaps in the archives everywhere, which they tried to remedy as soon as possible. See Toebak 1991, 78-79.

\section{The Resumption of Miracles}

'A ${ }^{\circ} 16124$ APRIL IS ALSVLLIKE MELAETSEN JONGMAN/ GENAEMPT PAVLVS GAVTIER HIEN [sic] GENESEN GEWORDEN OVER/ DIE VERDIENSTEN VAN S. LENAERT./ ${ }^{\circ}$ 1612 davril le 4 jour Paul Gautier icy pourtraict estroupié/ par les merites St Leonard est gary comme voyez'.

$2 \quad$ KR 1612, unfoliated (April 1612): 'Betaelt Meester Jacop Lambrechts, Schilder, voor het contrefeytsel van het mirakel van Paulus Gautier 4 gulden'. For other references to Lambrechts, see KR 16o6, unfoliated (receipts in money); KR 1612, unfoliated (June 1612); RAL, SL, no. 3622, fol. 73 .

$3 \quad$ Kriss-Rettenbeck 1958; Kriss-Rettenbeck 1972; Brauneck 1978, 89-94; Frijhoff 1985; Freedberg 1991, 136-16o; Jacobs 2013. For a recent criticism on Kriss-Rettenbeck, see Van der Velden 200o, 211-212 and 227-229.

4 Whereas Kriss-Rettenbeck qualified the inscription as distinguishing feature, Jacobs emphasized the direct visual communication between devotee and cult object within the painting. For definitions, see especially KrissRettenbeck 1958, 12 and 112; Brauneck 1978, 89-94; Jacobs 2013, 7-10.

Van der Velden 200o, 218-219; Jacobs 2013, quote on 1.

6 'T'AYANT INVOQUE EN CESTE/ CHAPELLE O DOUCE VIERGE SUIS IE/ MIRACULEUSEMENT DELIVRE/ EN MON AGE DE 4O ANS DUNE/ ROMPURE QUI M'AVOIT OBLIGE/ A PORTER CEST BRAYER PLUS/ DE 12 ANNEES. AD MAIOREM DEIPARE GLORIAM./ EX VOTO/ A.W.' Canvas, $78 \times 6$ o $\mathrm{cm}$. See Harline 2002 and Harline 2003 .

7 Compare with Kriss-Rettenbeck 1958, 12; KrissRettenbeck 1972, 119 and 214-216; Jacobs 2013, 7-10.

8 Even tabella votiva could refer to a text board. See for instance Erasmus 1965, 299, and Halkin 1969, 25 o. 
9 Vrancx 16oo, 267; Wichmans 1632, 258-261.

10 Giraldo 1959b, 103-107; Kriss-Rettenbeck 1972, 75,119 and 214-216. This type of imagery is also briefly discussed by Benz 2014, 8o-82. It should however be noted that similar wording was occasionally also used to refer to genuine votive gifts, and Platelle 1968, 32 and 53 used 'tableau commémoratif' to refer to votive paintings.

'(...) ghelijck sy daer inde cappelle oock hanght gheschildert, tot een eeuwighe memorie en ghedinckenisse van dit Mirakele wtnemende groot en schoone'. Vrancx 16oo, 19.

13 For examples, see Giraldo 1959b, 103-107 and Delbeke et al. 2015 .

14 '(...) ghegeven tot hoveschede bi miner vrouwen bevelen 1 man van die vanden Bosche, die hoer brochte 1 bort daer op ghemalen stont de miracle van onser vrouwen beelde die daer is, 1 oude scilt'. De Boer 1998, 210-211.

15 Tanghe 1862, 94-95; Giraldo 1959b, 104.

16 Laenen 1919-1920, vol. 1, 95-113; Périer-d'Ieteren 1975; Périer-d'Ieteren 1976; Cat. Brussels 2013, cat. 86. For the elevatio of his relics, see De Munck 1777, 246-252.

17 In general, see Kriss-Rettenbeck 1972, 75 .

18 'Drie verwoede menschen ghequelt vanden vyant/ werden hier oec verlost soe wij lesen'. Pannier-Deslypere 1980; Van Mulder 2016, 100-102. '(...) soo t'selve blyckt breeder by d'opene brieven van de stede van Dendermonde in t'iaer 1593'. See also Vrancx 16oo, 137-138 and Müller-Hofstede 1957, 133-134.

21 '(...) twelcke sy insghelycx verkent heeft op den xvii $^{\text {en }}$ iuny 1603 voor schepenen deser heerlicheyt van Sente Pieters'. See Daem 1990a, 33, and Daem 199ob, 229 and 242-244. The author erroneously refers to them as votive offerings.

Among the most recent studies on seventeenthcentury shrines in the Low Countries are Duerloo \& Wingens 2002; Harline 2002; Harline 2003;

Delfosse 20o9; Perneel 20o9; Delbeke 2012;

Dekoninck 2013; Adam 2014; Delbeke et al. 2015;

Constant 2015 .

23 Toebak 1992, 131-132. See also the remarks in Ditchfield 2007.

24 Van der Steen 2015.

25 On the situation in Brabant, see Toebak 1991 and Toebak 1992. On the southern Low Countries in general, see Thijs 1990; Marnef 2003; Pollmann 2011a, 125-158.
26

In general, see Harline 1990, 250-254; Forster 1992; Forster 2001; Ditchfield 2007. For the Low Countries, see Harline \& Put 20oo. For Brabant in particular, see Toebak 1992. For an excellent recent historiographical overview, see Laven 2006.

27 'Hoe is den tijdt aldus verkeert?/ Veel Sancten en zijn niet meer gheeert/ In dese Vlaemsche Landouwen/ (...) Alle die Sancten sijn gaen duycken/Sy en doen geen mirakel meer'. Mak 1946, 161.

28 For early reactions to the Beeldenstorm, see Göttler 1997, 62-64; Van Deursen 2001, 25-26; Duke 2oo9, 179-18o; Pollmann 2016, 159-162.

29 The full caption reads: 'Laet ons wel bidden sonder ophelden/ Och dat ons heylichdom te meer mach gelden./ Laet ons ras keren en worden niet moe/ Want aelle dees cremekie [sic for cremerie] hoort den duyvel toe' (below), and 'Tis al verloren, ghebeden, oft ghescheten/ Ick heb de beste canse ghestreken/ 1566' (above). On this print see especially Göttler 1997 and Duke 2009, 191-193.

'Dolendum tamen, non omnia miracula (siquidem solummodo decem \& octo authentice subsignata penes me habeo) esse scripto commendata: quod \& aliis quam plurimis sacris locis commune fatum est'. Wichmans 1632, 459. Cat. Leuven 1997, 249-253; De Landtsheer 2004, 73-74.

32 The last two dated miracles in the manuscript supposedly took place in 1461 and 1526 . Van Mulder 2010 and Van Mulder 2016, 87-94 and 339-341.

33 'Et quae hactenus dedi, unius ferè saeculi sunt (duo excipio) id est ab anno M. CCCC aut circa, ad annum quingentesimum, imo ad eum non pertingunt. Deinceps usque ad hoc nostrum aevum ferè silentium est, an non incuria, aut omissione eorum, qui Actis praefuerunt? Ego arbitror: sive etiam satietas eos cepit scribendi aut colligendi, cum viderent Divae gloriam satis iam propagatam testatamque esse. Neque enim desiisse miracula, vel haec aetas dicit: in qua paucis ab annis memorabilia evenere: quae tamen non Actis comprehensa, sed Tabulis ferè votivis signata, aut depicta, breviter hic commemorabo'. Lipsius 16o4, 65-66. Winnepenninckx 1964; Andriessen 1987.

35 'Dwelck deur de ketterye van Luther, en meer andere die de Heylighen Sancten en Sanctinnen 
versmaen is wt de ghewoonte ghegaen'. Vrancx 16oo, 152-153. Compare with 209. For instance Vrancx 16oo, 257, 259 and 266. '(...) datter noch daghelicx souden Mirakelen werden ghedaen, waert dat sy daghelicx noch aenroepen en versocht wierdt, dwelc deur de ketterye hier en elders is verkaut'. Vrancx 16oo, 2o9.

Vrancx 16oo, 152-153.

'Oversulcx de Mirakelen, die noch daghelicx in de heylighe Catholijcke Kercke op diveersche plaetsen gheschieden, en dienen niet verzweghen, ende zijn profytelick gheweten in plaetsen'. Vrancx 16oo, 4-5.

'(...) die stonden gheschreven in eenen Boeck van Perkemijn met volcommen bescheedt, die vande Gheusen ghevonden ende ghebroken is gheweest, wt den haet die sy draghen op God, zijn lieve Moedere en alle Heylighen'. Vrancx 16oo, 281, 283.

Vrancx 16oo, 117-118, 127.

Vrancx 16oo, 20, 28, 58, 127 and 152-153.

In general, see Van Mulder 2016, 335-35o.

Van De Woude 1950. 58.

Quoted from Van Mulder 2016, 95-98. 341-343.

Dekoninck 2013, 15 o.

'Lecteur Catholique, par les extraitz cy dessus desen deerlicken tijt vande leste eeuwe, alster soo veel Menschen in ongheloovicheyt en diveersche ketteryen ghevallen zijn, ende noch vallen in veel

'(...) antiquiteyten en oude Rekeninghen vande kercke van Tongre'. Vrancx 16oo, 37-63, quote on

Histoire 1753, esp. 46, 67 and 101; Indestege 1948; Hens et al. 1978, 72; Van Mulder 2016, 83-85 and transcriptz \& la narration de tant de miracles suffisamment verifiez, on peut clairement cognoistre, combien est grande \& effrontée l'impudence des Heretiques de nostre temps, $\&$ particulierement de ceux qui ont tenu nostre ville de Bruxelles, qui oserent publier en l'an 1581 un placart, dans lequel, entre eultres blasphemes, calumnies \& impostures, ilz misrent en avant, que ce S. Sacrement a esté manifesté premierement en l'an 1529 durant la maladie, que l'on appelloit lors, la Sueur d'Angleterre, de laquelle avons parlé cy dessus en nostre Histoire. Et neantmoings par le mesme placart ilz ne peuvent dissimuler, que plus de cent ans auparavant on en parloit'. Ydens 16०5, 236-237.
See also Adam 2014 and Van Mulder 2016, 106-115. The text of the placard can be found in Waerachtich verhael 1581.

'(...) s'apparut a luy en vision, en la mesme figure, comme il est monstré en ladicte Eglise (...) en memoire de ce grand benefice, \& pour action de grace, feist peindre un tableau, representant saditte vision avec la soubscription de ce beau Miracle'. Ydens 16o5, 205-206.

51 ' (...) doende daer af een tafereel maken, dat hy nae Cheevre ghezonden heeft in danckbaerheyt'. Vrancx 16oo, 30.

Wichmans 1632, 290 ('in beneficii accepti gratam testificationem').

53 Molanus 1570, fols. 83v-84v ('depictam tabellam testem miraculi’); Molanus 1996, vol. 1, 266-267.

54 Kriss-Rettenbeck 1958, 109-110; Brauneck 1978, 9o-91; Frijhoff 1985, 39-40; Jacobs 2013, 5-7.

55 Some rare examples are discussed in Giraldo 1959b, 107-108, and Zuring 1991, 99-103.

56 Vrancx 16oo, 3o, 104; Lipsius 16o4, 65-67 (1591); Wichmans 1632, 290, 499 (1604).

57 Lipsius 1604, 74 mentions a tabula dating to 1455 , depicting Duke Philip the Good kneeling in front of the Virgin and including a French inscription, but the painting's precise function remains unclear. Van der Velden 200o, 279 interpreted it as a commemorative epitaph rather than a votive painting or portrait. Jan Gossart's 1517 Diptych of Jean Carondelet (Paris, Louvre) has been interpreted as ex-voto, but does not meet any of the criteria: it does not represent a specific miraculous image or a miracle, nor was it given to a specific shrine. For the proposition, see Ainsworth 2010, cat. 40.

$5^{8} \quad$ Lipsius 1604,14 . See also 65-66.

59 Van Marnix van Sint Aldegonde 1868, vol. 1, 281.

6o See, respectively, Lipsius 16o5, 18 ('tafereelen, die wt devotie gheschoncken zijn') and 72 ('beloofde tafereelen'), and Lipsius 16o7, 22 ('tafereelen, die aldaer ghegheven zijn in ghedenckenisse van eenighe mirakelen ende ontfanghen weldaden') and 106-107 ('gheschildert in tafereelen tot memorie aldaer ghegeven'). On these translations, see Cat. Leuven 1997, cat. 78-79; De Landtsheer 2004, 84-85; Hermans 2015.

61 Theys 1953 and Theys 1960, 391-392. For another documented example in Ghent (Our Lady, 1631), see Daem 1990a, 39-40, and Daem 199ob, 229.

62 Van der Velden 200o, 166-178; Bass 2007. 
63 'VIRGINI DEI GENETRICI/ A morbo restitutus/ ROGERIVS CLARISSE sua [impensa] f./ MDCXIIII'. Smellinckx 2010. On Clarisse, see Vlieghe 1987, cat. 84; Timmermans 2008, 17, 112, 124 and 239-240.

64 Frijhoff $1985,39-40$. Similar observation by Van der Velden 2000, 218, with a hypothetical explanation of the difference between Italy and northern Europe on 282-285.

65 Wichmans 1632, 459. Compare with Büttner 1994.

66 '(...) daer men ghewaer wordt dat aen de memorien der Heylighen miraeckelen gheschieden'. Costerus 1604, 259 .

67 Platelle 1968, 45 ('un climat miraculeux'). Compare with Johnson 1996, 202, who spoke of 'a culture of the miraculous' in the Palatinate. For a brief overview of the early seventeenth-century Low Countries, see Platelle 1973.

68 Platelle 1968, 37-45.

69 Numan 1604, 33-35; Goetschalckx 1902a, 387; Duerloo \& Wingens 2002, esp. 23-28.

$70 \quad$ Numan 1604, 39-43 and passim; Duerloo \& Wingens 2002, 37-39 and 56-64.

71 Vrancx 160o, 4-5 and 152-153; Costerus 1604, 259 ('(...) op dat wy door de miraeckelen in het gheloove souden bevesticht worden'); Delfosse 2002; Delfosse 2009, 25-54.

72 '(...) up dat een yeder int gheloove ende moghentheyt Gods met zijne ghebenedide moeder ghesterct zij ende daerinne niet en twijffele'. Daem 1990a, 33 .

73 Ditchfield 2007, esp. 213.

74 On Petri, see Waite 2007, 40-41.

75 Waite 2007, 34, 41 and 49.

76 '(...) nochtans wordt de heylige kercke oock nu ter tijdt met veel miraeckelen, die gheschieden aen de heylighe beelden ende reliquien der Heylighen, verlicht, ende de waerheydt van ons gheloof bevesticht'. Costerus 1591, 28-30.

‘...) nae bequaemheydt de by-gheleghen heylighe plaetsen besoecke daermen ghewaer wordt dat aen de memorien der heylighen miraeckelen gheschieden'. Costerus 1604, 259.
84 In general, see Soergel 1991 and Pollmann 2o11a, 167-168. For other examples, see Histoire 1753 , 124-125; Hansay 1932; De Boer 2013, 65-68.

85 'Noch de guesten en hebbet Cruys niet connen nemen, maer alst sij inde kercke voerschreven mijnden de bilden te verbranden soo sijn sij int vier gevallen'. See the documents published online by Heemkring Campenholt: 'Mirakels te Everberg (1588)' (accessed 6 June 2019).

Marnef 2009, 88. The story is recounted in many later publications, including Wichmans 1632, 919-920. See also Delbeke et al. 2015, 229.

Platelle 1968, 27-37.

\section{'La coleur est artificiele, si j'ay jamais cognu} coleur de painctres'. Poullet 1877-1896, vol. 3, 543 . Van der Linden 1941. Toebak 1992, 134.

$$
\text { Lipsius 1604, unpaginated ('Historiam scripsi') }
$$
and 15-18. Compare with Benz 2014, 89.

\section{Benz 2014.}

'Den 4en april als het mirakel ghebuerde over Pauls Gautier van Limborch ende den 5en alsmen een solemnele messe dede in Sinte Leonaerts choor in danckbaerheyt die custers van luyen den 4 ende 5 ghegeven, 12 st. Noch aen andere 3 luyers 18 st. Den personnet vande messe te doen 5 st. Aen 7 potten bier voor die luyers 10,5 st. Die gareelmaker voor een riem vande groote clocke die wuyt gevallen was 13 st'. KR 1612, unfoliated (April 1612).

94 'Heer Willem Marien gherestitueert het gheens hij hadde Merten Reers ghegheven die naer Gheldenaken ghesonden worden om sekerheyt te hebben van het $2^{\text {en }}$ mirakel die sanderdaechs was ghebuert als Pauls van Limborch ghesondt worde, 20 st. (...) Als den pastoor met ons secretaris naer Gheldenaken reden om sekerheyt te hebben van het mirakel aen een vrau persoon betaelt voor peertshueren, 30 st. (...) Op 20 september alsmen luyde voor het mirakel vanden man van omtrent Lueven betaelt aende luyers 6 st'. KR 1612, unfoliated (April, June, September 1612): 'Livina de Hont die seyde hier verlost te syne van haren cruepelheyt haer ghegheven tot teerghelt 2 gulden 1o st. Voor die selve een lyffken costen 2 gulden 8 st. Den maeckloon 6 st. Die costers van luyen als het mirakel ghebuerde 15 st. Die selve vande messe van devotien 15 st'. The miracle in June 1612 might have happened at the occasion of Saint Leonard's procession at Whit Monday (1 June). 
'Lost doch wt prangghen die ligghen ghevanghen/ En croepele maect gaende ter deser vaert/ Blust elcx verlanghen in pynen verhanghen/So wort hi van elcken devotelijc verclaert/Lof heilich patroon te Leeuwe sinte Lenart'. See also Thijs 1991, 78.

The original foundation charter is lost, but copies exist in DAZ, no. 45, 142, and in RAL, КAB, no. 991, 140. See also Bets 1887-1888, vol. 2, 88, and Grauwen et al. 1996, 316, no. 1453. The foundation is also mentioned by Gramaye in 16o6: Gramaye 1968, 131-132.

Gaffiot 1934, 1321.

Brussels, KIK-IRPA, dossier no. 2L47 $20020775^{2}$. I am grateful to Emmanuelle Mercier for kindly providing me the necessary information. This particular intervention is not documented, but other restorations are: KR 1480, fol. 3 ov (June 1480); KR 1481, fol. 65 (April 1481, 'betaelt Meester Aert dij Scildere van Sijnte Lenaert te stoffere'); KR 1505, fol. 25 (June 1506); KR 1547, fol. 28 ov (June 1548, 'betaelt meester Anthonis die Schieldere (...) van Syncte Leonardt te stoefferen'). In general, see Bergmann 2017. Wichmans 1632, 499; Coveliers 1912, 76-78; Breugelmans et al. 1987, 69 .

Minnen 2011, vol. 1, 148.

Van De Woude 1950.

Piot 1859-186o, 31-41; Bets 1887-1888, vol. 2, 208-228.

KR 1598, fol. 199v: 'Peeter Briers en Aerdt van Haughen om naer Ons L. Vrau van Hal te gaen, gegeven 4,5 gulden'. For the miracles in Halle, see Vrancx 16oo, 6-15; Lipsius 16o4. See also Platelle 1973, 175 .

Wichmans 1632, 457. Goetschalckx 1910, 399-402. Stiennon 1951, 290; Russe 1955; George 2001, 264. Chapeaville 1612-1616, vol. 3, 643-644; Russe 1955, 380; George 2001, 265.

It was reportedly titled De l'invocation et de l'intercession des Saints, avec la vie de saint Léonard et les miracles advenus par ses mérites au foubourg de la cité de Liège, but no actual copy is known. See Acta Sanctorum Novembris III, 145, col. E; De Becdelièvre 1836-1837, vol. 1, 364; Wauters 1884-1885, col. 547 .

Hermans 2004, 128-133. Chapeaville 1612-1616, vol. 3,643 .

KR 1612 (unfoliated): 'Peeter van Lier voor een paer aude schoen voor Paulus van Limborch daer die mirakel in Sinte Leonaerts choer over

ghedaen was, 15 st (...) Paulus Gautier van Limborch als hy naer Hakendever ginck om aldaer inde prosessie te gaen ende Godt den heere dancken van dat hij soe miraculueselycken was ghenesen, hem ghegheven 4 st (...) Paulus Gautier als hy naer Bastonien reysde, 2 gulden 10 st. Betaelt Dirick Buys voor een paer schoen voor Pauls Gautier, 35 st (...) [April] Als Pauls Gautier naer Scherpenhuevel reysde met dij Predicant, hen tot teerghelt ghegheven 27,5 st (...) Betaelt aen Aerdt Moleneers die montcosten van Pauls Gautier, 4 gulden (...) [August] Suster Marie Gilis betaelt soe van lynwaet, den montkost van Paulus van Limborch die ghenesen is van syne cruepelheyt, 4 gulden'. Easter Monday in 1612 fell on 13 April.

112 Nilson 1999, 108.

113 KR 1613 (unfoliated): '[April] Duer ordonantie vande magistraet ghegheven onsen pastoor Struyven om die bullen oft brieven tot Mechelen aen den bischop te halen die de bullen van Roomen van sijne Heylicheyt hadde ontfanghen'. KR 1614 (unfoliated): '15o ghedruckte brieven om den afflaet te condighen (...) Den selven [Lenaerdt Straels] betaelt vanden afflaten te drucken'. KR 1616 (unfoliated, March and May 1616).

114 KR 1619 (unfoliated, 'den solisitatuer vanden afflaet vercreghen in april 1619 voor 7 jaeren, 12 gulden').

115 Compare with Van Herwaarden 1983, 418 and Tingle 2015, 54-55.

116 RAL, KAB, no. $1240 B$. See also the 1625 inventory, mentioning 'Die neeuw indulgentien deur Paulus papa verleent': De Ridder 1908, 54. Similar formulations equally occur in other indulgences awarded by Paul V. See for instance the printed edition of a Dutch translation awarded to Scherpenheuvel in Amsterdam, Rijksmuseum, inv. no. RP-P-OB-81.407.

117 A similar example in Wezemaal, 1635. See Minnen 2011, vol. 1, 177-179.

118 Compare with an example in Alsemberg: Theys 196o, 351 and 395 .

119 KR 1612 (unfoliated): ‘[April] Ons borgemeester Minten ghegheven als hy naer Hoye reysde om attestatie te hebben van Pauls Gautiers lamheyt, 4 gulden (...) Heer Willem Marien gherestitueert het gheens hij hadde Merten Reers ghegheven die naer Gheldenaken ghesonden worden om sekerheyt te hebben van het $2^{\text {en }}$ mirakel die sanderdaechs was ghebuert als Pauls van Limborch ghesondt worde, 20 st (...) [June] 
Als den pastoor met onsen secretaris naer Gheldenaken reden om sekerheyt te hebben van het mirakel aen een vrau persoon betaelt voor peertshueren 30 st'.

Compare for instance with the case of Wezemaal in 1635 , where it was the parish priest who took the principal initiative: Minnen 2011, vol. 1, 177-179. De Landtsheer 2004, 82-83; Benz 2014, 90; Van den Abeele 2015, 9-14.

\section{Devotional Negotiation with the Archducal Government}

RAL, SL, no. 3622 , fol. 34 ('die heylige reliquie van onsen patroen Sinte Leonaert').

KR 1616, unfoliated (November 1616): 'Den pastoor om naer Brussel te reysen om te vervolghen van eenighe reliquien te vercryghen van Sinte Lenaert (...) Willem den bode naer Brussel gesonden om naer die reliquie te vernemen (...) Den pastoor als hy naer Brussel reysde om die reliquien (...) Pastoor broer als hy oyck naer Brussel om die oyrsake gonck (...) Jan Bollen, borgemeester, op den 20 november als hy naer Brussel reysde inde sake van Sinte Lenaerts reliquie (...)'. KR 1616, unfoliated (December 1616) 'Jan Bollen borgemeester op geleet tgheens hy heeft verleet int soliciteren vande reliquien vanden reliquien van onsen patroon van Sinte Leonaert'. Vlierbeek, Heemkundige Kring, A3.5.8a. I am grateful to Robrecht Janssen for helping me to bring this document to the surface again. For Lemmens, see Smeyers 1964, 101-102.

Platelle 1968, 32.

AAM, Acta episcopalia Mechliniensia, reg. no. 5, fol. 131v. A transcription of that document is included in DAZ, no. 45, 158-159.

A transcription of the official report of the translation written by Abbot Lemmens is included in DAZ, no. 45,158 . It is published in Bets 1887-1888, vol. 2, 133-134.
The most important previous literature on the Zoutleeuw relic is Wilmet 1938, vol. 1, 242-244; Van Roey 1910, 26-28; Smeyers 1992, 41; Coningx 2009, 52-53.

Reinle 1988, 3-23; Angenendt 1994, 168-172;

Gardner 1994, 10-11.

Compare with Christian 1981, 127, and Vanhauwaert \& Geml 2016, 117-118, discussing the 'gradation of the visibility of the relic'. Compare KR 1589, fols. 244v-245 (May 1589, 'het beelt van Sinte Leonardt') with KR 1619, unfoliated ('Te Pinxten 8 draghers die het beelt van Sinte Leonaert droeghen (...) 2 jonghen met flambeauwen die voor die reliquie van Sinte Leonaert ghinghen').

'Een berrie (...) daermen het reliquium op draecht', and 'In de choor van Sint Lenaert rusten en worden bewaert syne H. reliquien, aen dese kercke gegeven ende solemnelycke gebrocht (...) door den eerw. heere Godefridus Lemmens, prelaet van Vlierbeeck, den 11 decembris 1616'. See respectively De Ridder $1908,52-53$, and Wauters 1892, 528-529.

Geary 1986, esp. 169 and 176; Angenendt 1994, 167-172; Schmidt 2003; Fricke 2015, 5-16; Vanhauwaert \& Geml 2016, 119.

13 Meyer 1950; Soergel 1993, 21-22 ; Schmitt 1999, 156-157; Vauchez 1999, 79-91; Brown 2007, 186; Fricke 2015.

Freedberg 1991, 119-120; Van der Velden 2000, 199-208.

15 Schreiner 1966, 33-5o; Angenendt 1994, 236-241; Joblin 1999.

16 For examples, see Duke 20o9, 19o-191, and De Boer 2016, 63-67.

Goetschalckx 1910, 401.

18 Christian 1981, 136-138; Burke 1984; Ditchfield 1993; Angenendt 1994, 243-244 and 250-251.

19 Ditchfield 1993.

20 Jansen 2013; Janssen 2014, 167-169; Van Strydonck et al. 2016, 115-116.

21 Quote from Camille 1989, 41-44. See also Walker Bynum 2011, 24-28.

-1914, vol. 4, 289.

Ford $2007,83,85$. Herremans 2015-2016. See also De Boer 2016, 72. Dinzelbacher 1990; Angenendt 1994, 102-122. On the tensions and interactions between images and relics, see Meyer 1950; Angenendt 1994, 183-189; Schmitt 1999; Zchomelidse 2016. 
Vanhauwaert \& Geml 2016, 117-119; Vanhauwaert 2018.

Compare with Vauchez 2004, 11-12.

Duerloo 2012, 377-378.

Lambert-Gorges 1993, 108.

Lonchay \& Cuvelier 1923, vol. 1, 221-222 and 358. The letter of elevation is in RAB, Secretarie van State en Oorlog, no. 179, fol. 53 (25 January 1616). Duerloo 2012, 87 and 377-378; Raeymaekers 2013,

Vermaseren 1941, 203-208; Benz 2003, 323-324; 77,176 and $231-232$.

Geary 1986, 182-183.

Duerloo 1997, 9-11 and 14. Van Lommel 1879 provides many examples.

Christian 1981, 135-136; Vroom 1992, 10-21; Lazure 2007.

Esser 2012, 182-184, 194 and 207-211.

The relevant documents and correspondence

have been published by Van Lommel 1879, $115^{-141 .}$

Huysmans 19o1, 315-317; Dresch 1925; Cat.

Brussels 1998, 265-266.

Pybes 1624 includes a report of the events and the certificate of authenticity. For Isabella's visit, see Viaene 1929.

'(...) grande devotion, honneur et reverence quil port au bienheureux Saint Leonard et desirant que ses saintes reliques soient mises, colloquees et gardees en lieu sacre et la où il leur soit faite toute reverence deue, et estant bien asseure quil les seront en leglise collegiale de Saint Leonard en la ville de Liau'. Vlierbeek, Heemkundige Kring, A3.5.8a.

For the persons present see RAL, SL, no. 3622 , as well as the official report of the translation in DAZ, no. 45, 158, and Bets 1887-1888, vol. 2, 133-134. Governor of town at that moment was Thomas de Wijngaerde.

For many examples of requests and complaints, see especially Bets 1887-1888, vol. 1, 202-232.

See RAL, SL, no. 3622 , fols. $41-43$.

'(...) requeste aendie heeren Staeten om te vercrygen eenige middelen tot reparatie deser stadt'. RAL, SL, no. 3623, fols. 39-41.

I am grateful to Dagmar Germonprez for generously sharing these data of her ongoing research with me. On the Archdukes' overall financial aid in the Low Countries, see Germonprez 2015.

Bets 1887-1888, vol. 1, 240-241.
George 2001, 265-272.

Rayssius 1628, 446-448. The shrines of Peutie and Sint-Lenaarts only claimed to possess relics of their patron saint in the later 17th and 18th centuries, respectively, and in 1770 a relic of Saint Leonard was authenticated for Vlierbeek abbey. See Van Heurck 1922, 373-375 and 402-404, and Smeyers 1992, 42.

Christian 1981, 141.

Pollmann 2011a, 164-165.

Wauters 1892, 528.

Joblin 1999, 134-135.

De Boer 2016, 64-65.

Vroom 1992, 8 and 15-21; Joblin 1999, 138;

Ditchfield 2007, 221.

Geary 1986, 179 .

Brown 2007; Herremans 2015-2016, 125.

See for instance Philip II's personal belief: Vroom 1992, 14-15.

Montgomery 2010, 99-115.

Christian 1981, 136-137.

The provenance of the relic is not mentioned in any of the contemporary sources, but an eighteenth-century history of Vlierbeek Abbey states that the relic came from Spain. See Brussels, KвR, Ms. 13.553, fols. 23r-v. No relic of Saint Leonard is mentioned as coming from the northern provinces in the collection of documents published by van Lommel 1879 .

See the many examples in Bets 1887-1888, vol. 1, 202-228, and Deracourt 1953.

Chipps Smith 2010, 38.

Nagelsmit 2014, 167-169.

Duerloo \& Wingens 2002, 28, 71-109; Thøfner $2007,281$.

Lombaerde 1998, 178-182.

Duerloo \& Wingens 2002, 97; Pollmann 2011a, 166.

Duerloo 2017, 157.

Thøfner 2007, 278-279; De Landtsheer 2004, 75. Duerloo \&Wingens 2002, 46; Germonprez 2015, 76-77. Compare with the similar example of Ekkergem (near Ghent) in Suykerbuyk 2018, 78-83.

$70 \quad$ Geary $1986,179$.

71 Achermann 1981; Geary 1986, 181 and 186; Angenendt 1994, 172-175, 247 and 250-251; Heinzelmann 2002. Achermann 1981, 110; Nagelsmit 2014, 170-173.

73 KR 1616, unfoliated (December 1616); RAL, SL, no. 3622 , fol. $38 \mathrm{v}$; DAZ, no. 45,158 . 
KR 1616, unfoliated (December 1616). RAL, SL, no. 3622 , fol. 71 . For the refugium, see Gramaye 1968, 127, and Bets 1887-1888, vol. 2, 177-178.

KR 1616, unfoliated (December 1616): ‘ 4 vaendraghers alsmen die reliquie met prosessie gonck halen int huys van Heylesim (...) 6 luyers (...) Die inde kercke sierden (...) Noch aen 2 fyn hatsen gecocht tot Thienen die branden voor het tabernakel int midden der kerken voor die reliquie'.

RAL, SL, no. 3622 , fols. $35 \mathrm{v}-38 \mathrm{v}$ and $71-73$

(damaged): 'Item die den lanterne hebben gehangen tusschen het misseclocxken ende den toren vanden stadthuys in het innecomen vandie heylige reliquie ... Item in het ... specktakel ... reliquie van ... Sinte Leonaert ... Vandie gaten toe te maken daer tabernakels hebben gestaen betaelt ... Jan Bollen Librechtsz. betaelt voer 92 voet berts bijden selven gelevert tot die poorte gestelt aen Willem Morren als die heylige reliquie waren innecomen ... [La]mbrechts, schilder, ... voerseide poorte ... zekere wapenen ...'

On Joyous Entries in the early modern Low Countries, see Soly 1984, Thøfner 2007 and Van Bruaene 2016b.

'(...) cum ymnis et canticis honorabiliter intronisate'. Goetschalckx 19o2b, 561 .

On the relation between the Roman catacombs and the circulation of relics, see Achermann 1981. For other examples in the Low Countries, see Platelle 1973, 233 and Nagelsmit 2014, 170-173. Buzelinus 1612; Houdoy 1879, 19o-191, nos. 8 and 9; Debièvre 1911, 118-121; Platelle 1968, 73-79; Lottin 1984, 274.

Dekoninck \& Delfosse 2016. On the Jesuits' interest in relics see Christian 1981, 137-138.

Vervaeck 19o7, 397-398; Duerloo 1997, 9 and 14; Van Wyhe 2004, 430-431; Duerloo 2012, 387-389.

Duerloo 1997, 9-10. Compare with Schraven 2014, 127-140.

Duerloo 1997, 10 and 14; Nagelsmit 2014, 166-167. In general, see Angenendt 1994, 250-251. Compare, for instance, with the elaborate description of a 1654 Swiss ceremony in
Achermann 1981, 104-109. Triumphal arches also occur in late sixteenth-century Spain, see Vroom 1992, 12.

87 Dinzelbacher 1990, 132-133; Walker Bynum 2011, 34.

88 Krautheimer 1969; Schraven 2014, 115-116. Compare with Angenendt 1994, 248.

89 Delehaye 1921, 213.

90 Krautheimer 1969, 176; Schraven 2014, 127-140, quote on 128.

91 Buzelinus 1612, sig. A3-A5.

92 Thøfner 2007; Van Bruaene 2016b.

93 RAL, SL, no. 3622 , fol. $35 \mathrm{v}$ ('alsmen die heylige relique vanden $H$. Patroen Sinte Leonaert heeft inne gehaelt'); KR 1616, unfoliated (December 1616, 'als die reliquie inne quampt').

94 Damen 2007, 248. In a similar vein, Schraven 2014, 128 interpreted relic translations from parish churches to the cathedral of Milan in 1576 as a visualization of 'the loyal submission of the parishes to the archdiocese'.

95 Harline 1990, 250-254; Ditchfield 2007; Pollmann 2011b, 99. For other case studies in the Low Countries, see for instance Toebak 1992; Harline \& Put 200o; Perneel 20o9; Delbeke et al. 2015, 244-245.

\section{Conclusion: The Thin Line Between Tradition and Transformation}

Cat. Los Angeles \& Madrid 2014. Halkin 1971, 88. Thompson translated it as 'a strange devotion', see Erasmus 1965, 6 . 'Bej meinem gedencken ist das gross wesen von S. Anna auffkomen, als ich ein knabe von funffzehen jharen war. Zuvor wuste man nichts von ihr, sondern ein bube kam und brachte $\mathrm{S}$. Anna, klugs gehet sie ahn, den es gab jederman darzu'. Quoted from Nixon 2004, 38. For the pilgrimages, see Clemen \& Leitzmann 1932-1934, vol. 1, 402-4O4, and Eber 2012. Du Val 1566, fol. 71 . Waerachtich verhael 1581; Ydens 1605, 229-23o. Klauser 1969, 137 . 